\title{
AKSF1 Isolated From the Rice-Virulent Strain Acidovorax avenae K1 Is a Novel Effector That Suppresses PAMP-Triggered Immunity in Rice
}

\author{
Takemasa Kawaguchi ${ }^{1}$, Minami Nakamura ${ }^{2}$, Hiroyuki Hirai ${ }^{1}$, Takehito Furukawa $^{1}$, Machiko Kondo ${ }^{1}$, and \\ Fang-Sik Che 1,2,3,† $^{-1}$ \\ ${ }^{1}$ Department of Bio-Science, Nagahama Institute of Bio-Science and Technology, 1266, Tamura, Nagahama, Shiga 526-0829, \\ Japan \\ ${ }^{2}$ Graduate School of Biosciences, Nagahama Institute of Bio-Science and Technology, 1266, Tamura, Nagahama, Shiga 526- \\ 0829, Japan \\ ${ }^{3}$ Genome Editing Research Institute, Nagahama Institute of Bio-Science and Technology, 1281-8, Tamura, Nagahama, Shiga \\ 526-0829, Japan
}

Accepted 28 October 2020.

\begin{abstract}
Microbial pathogens deliver effectors into plant cells to suppress plant immune responses and modulate host metabolism in order to support infection processes. We sought to determine if the Acidovorax avenae rice-virulent $\mathrm{K} 1$ strain can suppress pathogen-associated molecular pattern-triggered immunity (PTI) induced by flagellin isolated from the rice-avirulent N1141 strain. The flagellin-triggered PTI, including $\mathrm{H}_{2} \mathrm{O}_{2}$ generation, callose deposition, and expression of several immune-related genes were strongly suppressed in K1 preinoculated cultured rice cells in a type III secretion system (T3SS)-dependent manner. By screening 4,562 transposontagged mutants based on their suppression ability, we found that 156 transposon-tagged K1 mutants lost the ability to suppress PTI induction. Mutant sequence analysis, comprehensive expression analysis using RNA sequencing, and the prediction of secretion through T3SS showed that a protein named $A$. avenae $\mathrm{K} 1$ suppression factor 1 (AKSF1) suppresses flagellin-triggered PTI in rice. Translocation of AKSF1 protein into rice cells is dependent on the T3SS during infection, an AKSF1-disruption mutant lost the ability to suppress PTI responses, and expression of $A K S F 1$ in the $A K S F 1$-disruption mutant complemented the suppression activity. When $A K S F 1$ disruption mutants were inoculated into the host rice plant, reduction of the disease symptoms and suppression of bacterial
\end{abstract}

Takemasa Kawaguchi and Minami Nakamura contributed equally.

${ }^{\dagger}$ Corresponding author: F.-S. Che; k_sai@nagahama-i-bio.ac.jp

Funding: This work was supported by the Japan Society for the Promotion of Science Grants-in-Aid for Scientific Research (JSPS KAKENHI) grant numbers 19K15843, and 19K15844 and by Private University Research Branding Project, Ministry of Education, Culture, Sports, Science and Technology, Japan.

*The $\boldsymbol{e}$-Xtra logo stands for "electronic extra" and indicates supplementary materials are published online.

The author(s) declare no conflict of interest.

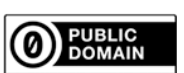

The author(s) have dedicated the work to the public domain under the Creative Commons CCO "No Rights Reserved" license by waiving all of his or her rights to the work worldwide under copyright law, including all related and neighboring rights, to the extent allowed by law. 2021 growth were observed. Taken together, our results demonstrate that AKSF1 is a novel effector that can suppress the PTI in a host rice plant.

Keywords: Acidovorax avenae, effector, effector-triggered susceptibility, flagellin, type III secretion system, PAMPtriggered immunity, plant immunity, rice

Plants have a multilayered immune system against invading pathogens. The first layer of the plant immune system involves pathogen perception using pattern recognition receptors to recognize conserved pathogen-associated molecular patterns (PAMPs). PAMPs include characteristic structures from pathogens, such as $\beta$-glucan (Klarzynski et al. 2000), polysaccharide chitin (Kaku et al. 2006), ergosterol (Laquitaine et al. 2006), lipopolysaccharide (Silipo et al. 2005), flagellin (Che et al. 2000; Felix et al. 1999), translation elongation factor EF-Tu (Furukawa et al. 2014; Kunze et al. 2004), and elicitin (Baillieul et al. 2003). The recognition of such PAMPs by the plant causes PAMP-triggered immunity (PTI) that includes the generation of reactive oxygen species (ROS), callose deposition, and expression of several immune-related genes (Boller and Felix 2009).

Among the various PAMPs that induce PTI, flagellin, the main component of the bacterial flagellum, has been the most extensively studied with respect to its PAMP recognition mechanism and downstream signaling events. In Arabidopsis, a synthetic 22-amino acid peptide (flg22) comprising the most conserved region within the $\mathrm{N}$-terminal portion of flagellin is sufficient to produce a PTI response (Felix et al. 1999). Recognition of flg22 depends upon FLS2 (flagellin sensing 2), a receptor-like kinase composed of an extracellular leucine-rich repeat domain, a single membrane-spanning domain, and a cytoplasmic serine/threonine kinase domain (GómezGómez and Boller 2000). We previously reported that PTI is induced by the CD2-1 region in flagellin rather than flg22. Furthermore, OsFLS2, the rice ortholog of FLS2 was not involved in CD2-1 recognition in rice (Katsuragi et al. 2015). These data indicate that rice mainly recognizes flagellin CD2-1 by a receptor distinct from OsFLS2 and that this epitope recognition leads to PTI.

Several plant-pathogenic bacteria can secrete effector proteins through bacterial type III secretion systems (T3SS). The second layer of the plant immune system involves the recognition of the effector. The recognition of an effector causes one of the sophisticated immune system responses called 
effector-triggered immunity (ETI), which is activated by the products of plant resistance genes following detection of individual effector proteins. The inherent role of the effector is to inhibit plant immunity such as PTI through susceptibility proteins (effector targets), thereby enabling host cell infection and resulting in effector-triggered susceptibility (ETS), which interferes with PTI responses and promotes bacterial virulence (Jones and Dangl 2006). Several PTI-suppressing effectors have been reported. AvrPto from Pseudomonas syringae interacts with the kinase domains of FLS2 and EFR (EF-Tu receptor in Arabidopsis) and leads to the suppression of PTI responses including mitogen-activated protein kinase (MAPK) signaling pathways. XopK derived from Xanthomonas oryzae pv. oryzae suppresses immune responses by ubiquitination of somatic embryogenic receptor kinase 2 (Qin et al. 2018).

The brown stripe disease caused by Acidovorax avenae, classified as a gram-negative bacterium, is a serious problem that is difficult to control and decreases rice yield drastically (Kadota et al. 1996). A. avenae can infect a wide variety of monocotyledonous plants; however, individual strains infect only one or a few host species each. We previously reported that the K1 strain isolated from rice can only infect rice plants (virulent), whereas the N1141 strain isolated from finger millet cannot infect rice (avirulent). Furthermore, when the N1141 strain infected rice, several immune responses, including $\mathrm{HR}$ cell death, $\mathrm{H}_{2} \mathrm{O}_{2}$ generation, and expression of immunerelated genes were induced. In contrast, no immune responses were observed in the K1 strain-inoculated rice cells (Che et al. 1999).

We reported that flagellin purified from the avirulent N1141 strain induced rice PTI responses, while the virulent K1 flagellin did not induce the PTI responses. (Che et al. 2000; Furukawa et al. 2014; Katsuragi et al. 2015; Tanaka et al. 2003). Mass spectrometry analyses and site-directed mutagenesis of the flagellin showed that the glycans at Ser178 and Ser183 in K1 flagellin prevent epitope recognition in rice (Hirai et al. 2011).

In many plant-pathogenic bacteria, several genes located within hrp (hypersensitive response and pathogenicity) clusters encode the T3SS apparatus and related proteins. We previously reported that the rice-virulent $\mathrm{K} 1$ strain has the hrp cluster containing genes that encode the T3SS apparatus and that the hrp genes of $\mathrm{K} 1$ are involved in virulence (Kondo et al. 2017). However, it is unknown if the K1 strain has the PTI-suppressing effector protein and, also, if $\mathrm{K} 1$ can suppress rice PTI.

Here, we show that several PTI responses induced by flagellin from the N1141 strain in cultured rice cells were reduced by inoculation with the $\mathrm{K} 1$ strain in a T3SS-dependent manner. The screening of transposon-tagged mutants, based on PTI suppression ability, sequence analysis, transcriptome analysis, and in silico prediction of T3SS-mediated secretion, showed that AKSF1 is a candidate ETS effector. AKSF1 gene disruption caused the loss of ETS ability and AKSF1 was transported from bacterial cells into plant cells through T3SS. When the AKSF1 disruption mutant was inoculated into the host rice plant, reduction of the disease symptoms and suppression of bacterial growth was observed. This work provides a new infection strategy through novel ETS effector of plant-pathogenic bacteria.

\section{RESULTS}

Evaluation of rice PTI suppression by the rice-virulent strain A. avenae $\mathrm{K} 1$.

To determine if the A. avenae $\mathrm{K} 1$ strain can suppress PTI induced by flagellin in rice, we attempted to characterize immune responses induced by flagellin protein purified from the rice-avirulent $A$. avenae $\mathrm{N} 1141$ strain. $\mathrm{H}_{2} \mathrm{O}_{2}$ generation is an established early PTI reaction. We therefore began by measuring $\mathrm{H}_{2} \mathrm{O}_{2}$ generation kinetics caused by N1141 flagellin in cultured rice cells. To estimate the effective concentration of
N1141 flagellin required to induce $\mathrm{H}_{2} \mathrm{O}_{2}$ generation in cultured rice cells, flagellin was added to cultured rice cells at several concentrations and $\mathrm{H}_{2} \mathrm{O}_{2}$ amounts were measured $1 \mathrm{~h}$ after N1141 flagellin treatment (Fig. 1A). The half-maximal effective concentrations were estimated at $46.8 \mathrm{nM} \mathrm{N} 1141$ flagellin. To clarify the time-dependence of $\mathrm{H}_{2} \mathrm{O}_{2}$ generation induced by N1141 flagellin, cultured rice cells were treated with $100 \mathrm{nM}$ purified N1141 flagellin, and the amount of $\mathrm{H}_{2} \mathrm{O}_{2}$ was measured $0,0.5,1,1.5$, and $2 \mathrm{~h}$ after treatment. The greatest amount of $\mathrm{H}_{2} \mathrm{O}_{2}$ generation was observed $1 \mathrm{~h}$ after treatment, and $\mathrm{H}_{2} \mathrm{O}_{2}$ levels were gradually reduced until $2 \mathrm{~h}$ after treatment (Fig. 1B). Based on the above experiments, we decided to use $100 \mathrm{nM}$ N1141 flagellin to determine the suppression of $\mathrm{H}_{2} \mathrm{O}_{2}$ generation by $A$. avenae $\mathrm{K} 1$.

Cultured rice cells were inoculated with the $\mathrm{K} 1$ strain for 0,2 , 3,4 , and $6 \mathrm{~h}$ before $100 \mathrm{nM} \mathrm{N} 1141$ flagellin was added to each of the preinoculated rice cell cultures. When N1141 flagellin

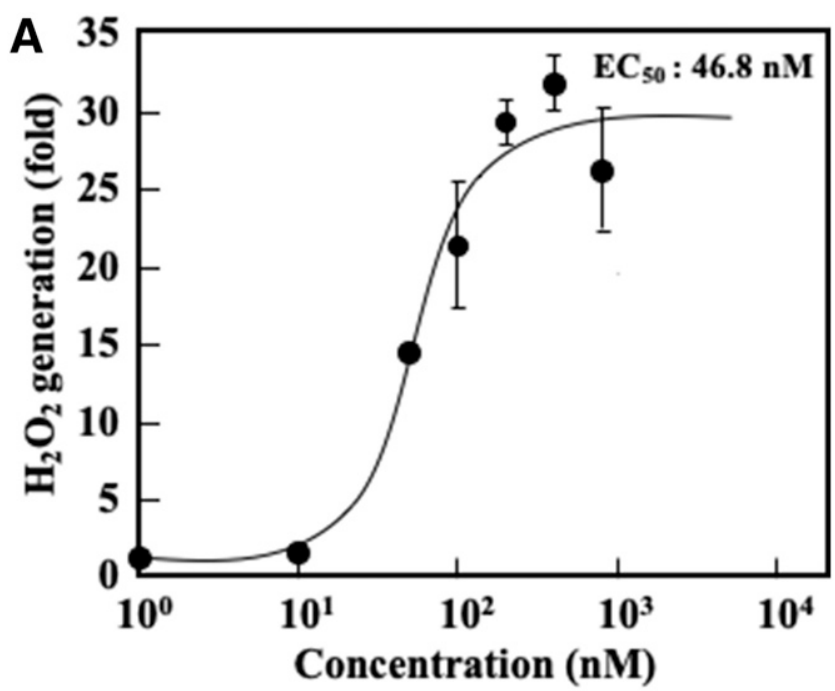

B

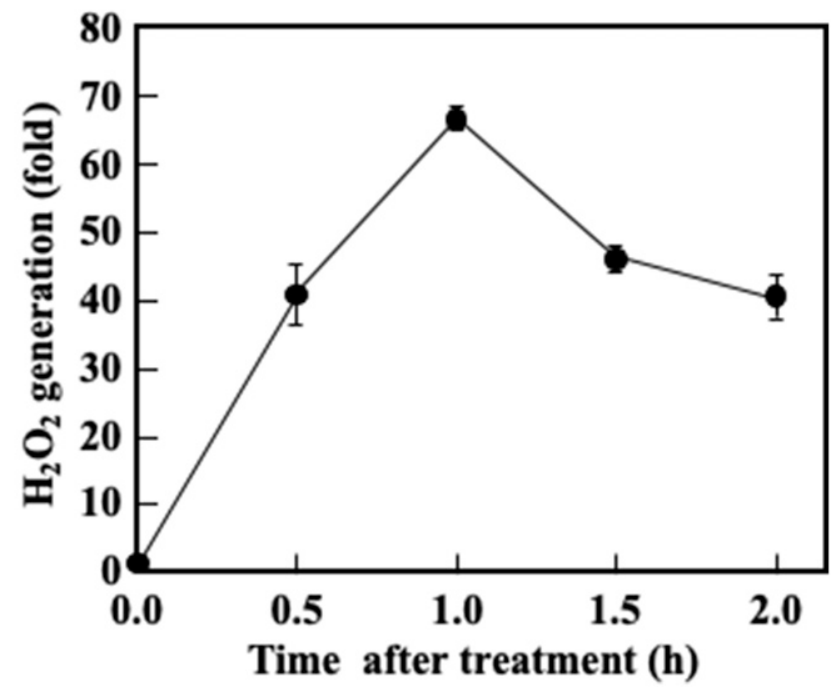

Fig. 1. Induction of $\mathrm{H}_{2} \mathrm{O}_{2}$ generation by flagellin isolated from the Acidovorax avenae N1141 strain in cultured rice cells. A, Dose-dependent induction of $\mathrm{H}_{2} \mathrm{O}_{2}$ generation in cultured rice cells by $\mathrm{N} 1141$ flagellin. $\mathrm{H}_{2} \mathrm{O}_{2}$ generation was detected $1 \mathrm{~h}$ after treatment with either $1,10,50,100,200$, 400 , or $800 \mathrm{nM}$ flagellin. The vertical axis represents fold change relative to the amount of $\mathrm{H}_{2} \mathrm{O}_{2}$ in cultured rice cells before flagellin treatment. Bars indicate the standard deviation of the mean of three independent experiments. B, Time course of $\mathrm{H}_{2} \mathrm{O}_{2}$ generation in cultured rice cells treated with $100 \mathrm{nM}$ N1141 flagellin. The vertical axis represents fold change relative to the amount of $\mathrm{H}_{2} \mathrm{O}_{2}$ in cultured rice cells before flagellin treatment. The bars show the standard deviation for three independent experiments. 
was added to cultured rice cells $2 \mathrm{~h}$ after preinoculation, the amount of $\mathrm{H}_{2} \mathrm{O}_{2}$ generated was half of that recorded for cultured rice cells that were not inoculated with $\mathrm{K} 1$. The magnitude of the increase in $\mathrm{H}_{2} \mathrm{O}_{2}$ caused by flagellin decreased with increasing inoculation times with the $\mathrm{K} 1$ strain, and no $\mathrm{H}_{2} \mathrm{O}_{2}$ was generated in response to $\mathrm{N} 1141$ flagellin by cultured rice cells inoculated with $\mathrm{K} 1$ for either 3, 4, or $6 \mathrm{~h}$ (Fig. 2A).

We also determined the suppression of callose deposition in cultured rice cells by the K1 strain, because N1141 flagellin induces both $\mathrm{H}_{2} \mathrm{O}_{2}$ generation and callose deposition (Katsuragi et al. 2015). Cultured rice cells were inoculated with K1 and, $3 \mathrm{~h}$ after inoculation, N1141 flagellin was added to the rice cells. When the rice cells were stained with aniline blue to visualize callose after $6 \mathrm{~h}$ of flagellin treatment, the callose numbers were reduced to about $20 \%$, as compared with uninoculated rice cells. (Fig. 2B; Supplementary Fig. S1).

We have reported that expression of the gene $P A L$, which encodes phenylalanine ammonia lyase, and the flagellininducible transcription factor encoding gene (OsWRKY70) were increased by N1141 flagellin treatment in cultured rice
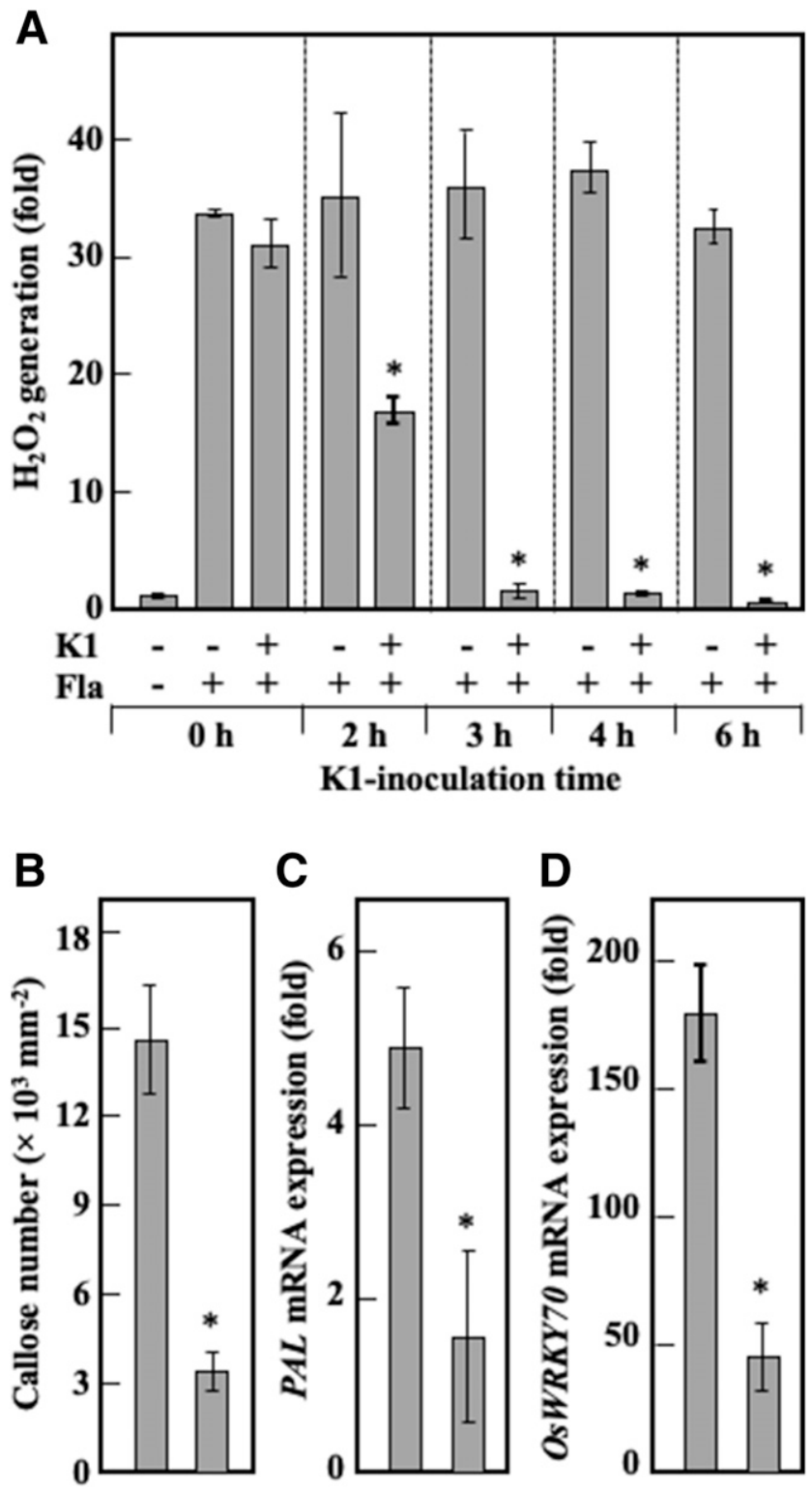

C

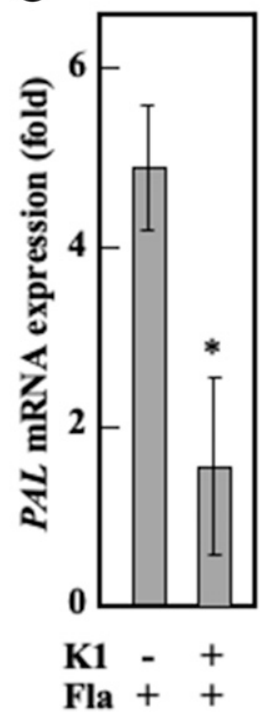

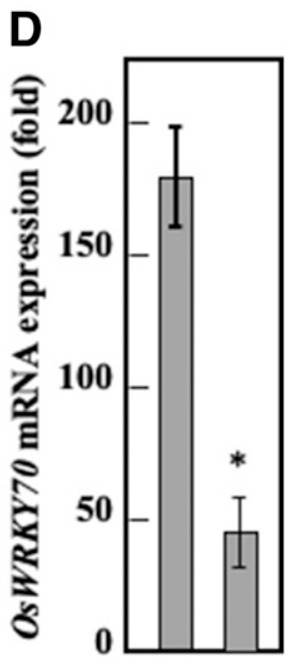

$\mathrm{K} 1-+$ $\mathrm{Fla}++$ cells (Takai et al. 2007). To determine whether the $\mathrm{K} 1$ strain also suppresses the induction of these genes in response to flagellin, the PAL and OsWRKY70 messenger RNA (mRNA) levels in K1-inoculated cultured rice cells were measured, using quantitative reverse-transcription PCR (qRT-PCR). Treatment with N1141 flagellin increased about fivefold in water-treated control cells, while an approximately twofold increase in $P A L$ mRNA was observed in K1-inoculated cultured rice cells (Fig. 2C). Level of OsWRKY7O mRNA in water-treated control cultured rice cells was 180 times higher following the flagellin treatment, while preinoculation with the $\mathrm{K} 1$ strain reduced the extent of the increase by about 50 times (Fig. 2D). Based on these experimental data, we concluded that the $A$. avenae $\mathrm{K} 1$ strain can suppress PTI induced by N1141 flagellin in rice cells.

\section{Roles of T3SS in PTI suppression by the K1 strain.}

We previously reported that T3SS-deficient mutants of A. avenae $\mathrm{K} 1$ (KDT3SS) caused no symptoms in rice and that Lrp of $\mathrm{K} 1$, which is secreted through the T3SS, functions as a virulence factor in rice (Kondo et al. 2017). To clarify whether the suppression of PTI by the K1 strain is associated with effector proteins, a PTI-suppression test using a T3SS-deficient mutant of $\mathrm{K} 1$ (KDT3SS) was performed. When cultured rice cells were inoculated with the $\mathrm{K} 1$ strain for $3 \mathrm{~h}$ before being treated with flagellin, the generation of $\mathrm{H}_{2} \mathrm{O}_{2}$ was reduced to almost the same level as that of the control (without K1 strain inoculation and without flagellin treatment). In contrast, the $K \Delta T 3 S S$-inoculated rice cells produced about seven times as much $\mathrm{H}_{2} \mathrm{O}_{2}$ as K1-inoculated cells (Fig. 3A). Similarly, for flagellin-induced callose deposition, the amount of callose deposited in K1-inoculated cultured rice cells was similar to that of the control, while the amount of callose deposited in $K \Delta T 3 S S$-inoculated cultured rice cells was about three times

Fig. 2. Suppression of N1141 flagellin-induced PTI responses by the ricevirulent Acidovorax avenae K1 strain. A, Suppression of flagellin-induced $\mathrm{H}_{2} \mathrm{O}_{2}$ generation in cultured rice cells by the $\mathrm{K} 1$ strain. Cultured rice cells were preinoculated with the $\mathrm{K} 1$ strain for $0,2,3,4$, or $6 \mathrm{~h}$ before $100 \mathrm{nM}$ flagellin was added to each preinoculated rice cell culture. Cultured rice cells were either inoculated with $(+)$ the K1 strain or were left uninoculated $(-)$ before being either treated with N1141 flagellin (+) or left untreated (-). The vertical axis represents fold change relative to the amount of $\mathrm{H}_{2} \mathrm{O}_{2}$ in control cells (without $\mathrm{K} 1$ strain inoculation and without flagellin treatment). Error bars indicate the standard deviation of five independent experiments. Asterisks indicate a significant decrease $(t$ test, $P<0.05)$ in $\mathrm{H}_{2} \mathrm{O}_{2}$ generation. B, Suppression of flagellin-induced callose deposition in cultured rice cells by the K1 strain. Cultured rice cells were either inoculated with the K1 strain (+) or were left uninoculated for $3 \mathrm{~h}$, and 200 $\mathrm{nM}$ flagellin was subsequently added to each preinoculated rice cell culture. Asterisks indicate a significant decrease $(t$ test, $P<0.05)$ in callose deposition. C, Suppression of flagellin-induced $P A L$ messenger RNA (mRNA) expression in cultured rice cells by the K1 strain. Cultured rice cells were either inoculated with $\mathrm{K} 1 \mathrm{(+)}$ or were left uninoculated (-) for $3 \mathrm{~h}$ before $100 \mathrm{nM}$ flagellin was added to each preinoculated rice cell culture. After $1 \mathrm{~h}$, the amount of $P A L$ mRNA was measured by quantitative reversetranscription PCR (qRT-PCR). The vertical axis represents fold change relative to the amount of PAL mRNA in control cells (without K1 strain inoculation and without flagellin treatment). Error bars indicate the standard deviation of five independent experiments. Asterisks indicate a significant decrease ( $t$ test, $P<0.05$ ) in $P A L$ mRNA. D, Suppression of flagellin-induced $O s W R K Y 70 \mathrm{mRNA}$ expression in cultured rice cells by the $\mathrm{K} 1$ strain. Cultured rice cells were either inoculated with the K1 strain $(+)$ or were left uninoculated $(-)$ for $3 \mathrm{~h}$ before $100 \mathrm{nM}$ flagellin was added to each preinoculated rice cell culture. After $1 \mathrm{~h}$, the amount of $O s W R K Y 70$ mRNA was measured by qRT-PCR. The vertical axis represents fold change relative to the amount of $O s W R K Y 70 \mathrm{mRNA}$ in control cells (without $\mathrm{K} 1$ strain inoculation and without flagellin treatment). Error bars indicate the standard deviation of five independent experiments. Asterisks indicate a significant decrease ( $t$ test, $P<0.05$ ) in $O s W R K Y 70$ mRNA. 
that of K1-inoculated cells (Fig. 3B). The expression level of $P A L$ was increased about 13 times with $100 \mathrm{nM}$ flagellin for $1 \mathrm{~h}$, and the expression level of $P A L$ in K1-treated cultured rice cells increased about three times that of the control. Interestingly, when cultured rice cells were inoculated with $K \Delta T 3 S S$ for $3 \mathrm{~h}$ before being treated with $100 \mathrm{nM}$ flagellin for $1 \mathrm{~h}$, the expression levels of $P A L$ increased about 22 times compared with the control (Fig. 3C). Similarly, the expression of OsWRKY70 mRNA was increased about eight times by the flagellin treatment, while the increased expression by treatment with the flagellin varied five times in $\mathrm{K} 1$-inoculated rice cells and 14 times in $K \Delta T 3 S S$-inoculated cultured rice cells (Fig. $3 \mathrm{D})$. These results indicate that the $\mathrm{K} 1$ strain suppresses flagellin-triggered PTI through one or more effectors secreted by T3SS.

\section{Identification of ETS effector genes.}

To identify proteins that function as ETS effectors, a tagged transposon library was constructed for the K1 strain. The workflow for high-throughput screening of ETS effectorencoding genes is described in Supplementary Figure S2. By screening 4,562 mutants according to this workflow, we found that the suppression activity of 156 transposon-tagged K1 mutants were reduced to the same level as $K \Delta T 3 S S$. Sequence analysis of the transposon neighbor regions, using the random amplification of transposon ends PCR (Ducey and Dyer 2002) method, revealed that the transposons were inserted into 68 unique genes.
Ralstonia solanacearum, which is among the most devastating plant-pathogenic bacteria, induces the expression of T3SS-related genes and effector-encoding genes when it senses the host plant (Wu et al. 2015). The nature of this induction in $R$. solanacearum suggests that expression of ETS effectorencoding genes in the $A$. avenae $\mathrm{K} 1$ strain may increase when the bacteria infect a rice plant. We therefore went on to attempt further selection of genes encoding effectors related to ETS from among the 68 genes. We first screened for changes in gene expression in response to infection. Cultured rice cells were inoculated with the $\mathrm{K} 1$ strain for $0,2,4$, or $6 \mathrm{~h}$, and total RNA were isolated from $\mathrm{K} 1$ cells. RNA sequencing was performed with an Illumina HiSeq 2500, based on the K1 strain genome data. After quantifying the signal intensities and normalizing them, we identified 1,240 genes in the $\mathrm{K} 1$ strain that were upregulated during the interaction between $\mathrm{K} 1$ and cultured rice cells, using a fivefold or greater difference in transcript levels before and after inoculation as our criterion (Supplementary Fig. S3; Supplementary Table S1). Among the identified 1,240 genes, 16 genes, identified by high-throughput screening using a tagged transposon library of the K1 strain, were included (Fig. 4A).

Bacterial effector proteins are transported into plant cells through the T3SS apparatus. Therefore, we determined whether the candidate ETS effectors possess the T3SS-dependent secretory ability, using the EffectiveT3 software, designed for amino acid sequence-based prediction of proteins secreted via the T3SS (Arnold et al. 2009). Among 16 candidate ETS
A

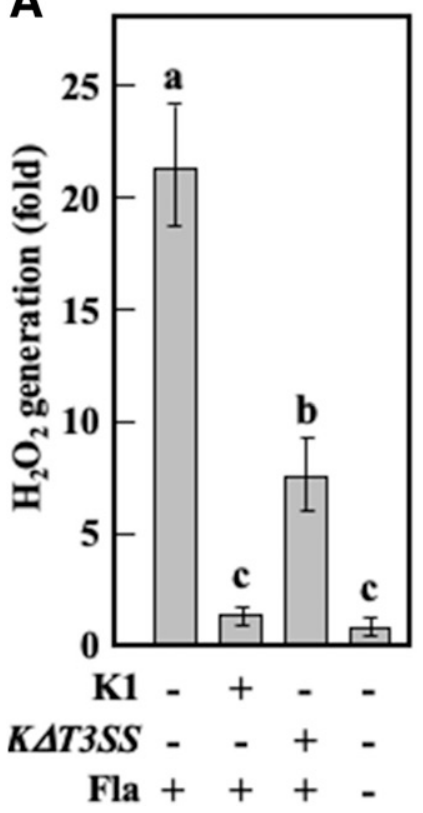

B

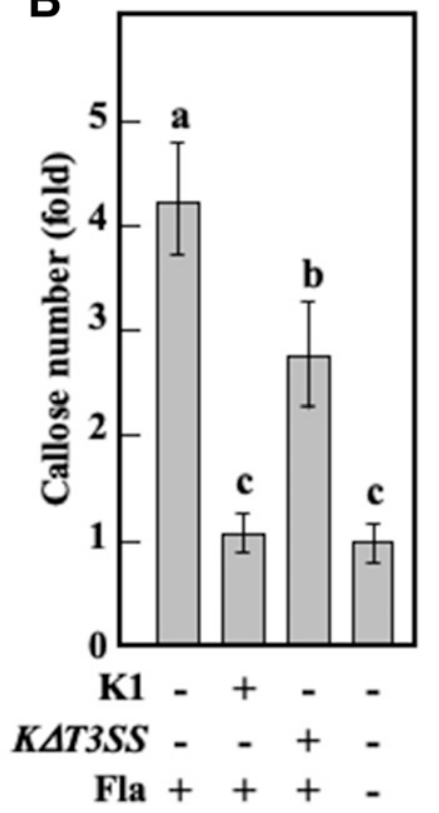

C

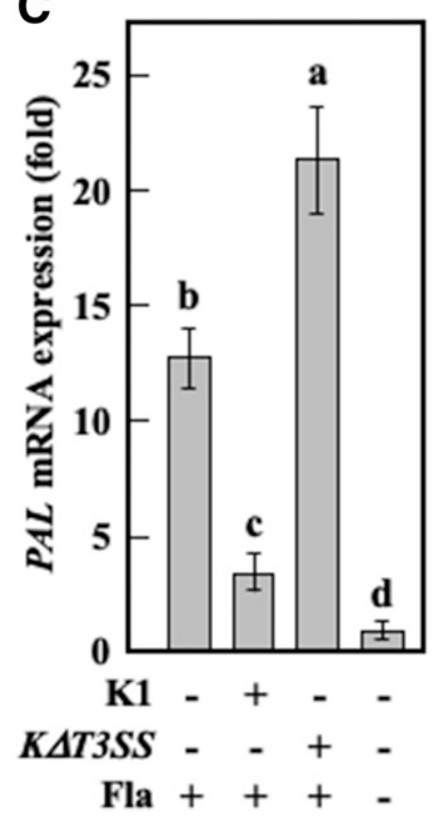

D

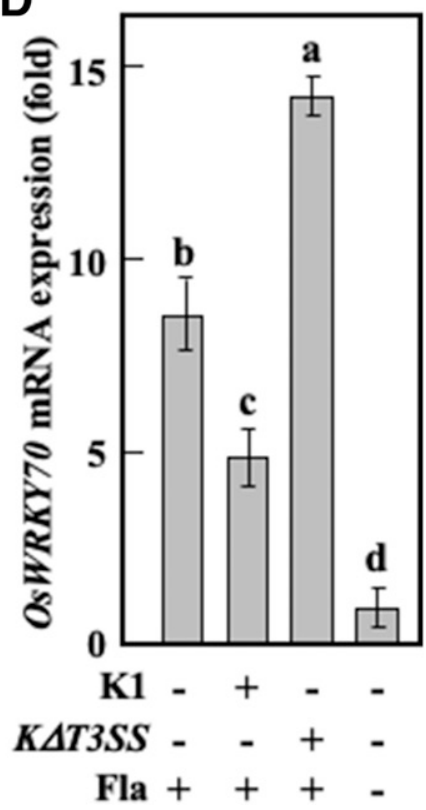

Fig. 3. Role of the type III secretion system (T3SS) on PTI suppression by the Acidovorax avenae K1 strain or KAT3SS. A, Suppression of flagellin-induced $\mathrm{H}_{2} \mathrm{O}_{2}$ generation in cultured rice cells by the $\mathrm{K} 1$ strain or $K \Delta T 3 S S$. Cultured rice cells were either inoculated with the K1 strain or $K \Delta T 3 S S$ (+) or were left uninoculated (-) for $3 \mathrm{~h}$ before being treated with $100 \mathrm{nM}$ flagellin. The vertical axis represents fold change relative to the amount of $\mathrm{H}_{2} \mathrm{O}_{2}$ in control cells (without $\mathrm{K} 1$ strain inoculation and without flagellin treatment). Amount of $\mathrm{H}_{2} \mathrm{O}_{2}$ generation in cultured rice cells without flagellin treatment did not differ between K1 preinoculation and water pretreatment. Error bars indicate the standard deviation of five independent experiments. Lower case letters above bars indicate significant differences according to the Tukey-Kramer test $(P<0.05)$. B, Suppression of flagellin-induced callose deposition in cultured rice cells by

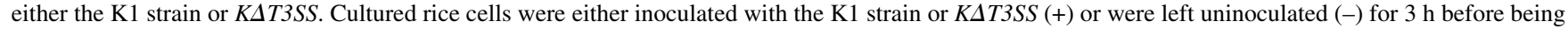
treated with $200 \mathrm{nM}$ flagellin for $6 \mathrm{~h}$. The vertical axis represents fold change relative to the amount of callose deposition in control cells (without K1 strain inoculation and without flagellin treatment). Error bars indicate the standard deviation of three independent experiments. Lower case letters above bars indicate significant differences according to the Tukey-Kramer test $(P<0.05)$. C and D, Suppression of flagellin-induced $P A L(C)$ or $O s W R K Y 70$ (D) expression in cultured rice cells by the $\mathrm{K} 1$ strain or $K \Delta T 3 S S$. Cultured rice cells were either inoculated with the K1 strain or $K \Delta T 3 S S(+)$ or were left uninoculated (-) for $3 \mathrm{~h}$ before being treated with $100 \mathrm{nM}$ flagellin. After $1 \mathrm{~h}$, the amount of PAL or OsWRKY70 messenger RNA (mRNA) was measured by quantitative reversetranscription PCR. The vertical axis represents fold change relative to the amount of PAL or OsWRKY70 mRNA in control cells (without K1 strain inoculation and without flagellin treatment). Error bars indicate the standard deviation of five independent experiments. Lower case letters above bars indicate significant differences according to the Tukey-Kramer test $(P<0.05)$. 
effectors, only one, encoded by Kgene_3339, was predicted to be secreted by the T3SS (Fig. 4B). This gene, AKSF1 (A. avenae $\mathrm{K} 1$ suppression factor 1 ), encodes a protein consisting of 208 amino acids. A homology search using the GenBank/EMBL database revealed that a domain consisting of amino acid residues 27 to 93 within AKSF1 shows 14\% identity to the DNA polymerase beta subunit N-terminal region in Escherichia coli. Furthermore, we found that the full-length amino acid sequence of AKSF1 shares $43 \%$ amino acid sequence identity with domain of unknown function (DUF) 4935
(Fig. 4C). The DUF4935 superfamily, which is uncharacterized, protein is mostly found in several bacterial species. Therefore, AKSF1 is a novel protein of unknown function, because we could derive no information on its function from our homology analysis.

AKSF1 secretion into rice cells.

To confirm the translocation of AKSF1 into rice cells, we monitored type III effector delivery, using an AKSF1-adenylate cyclase (Cya) hybrid protein. CyaA requires calmodulin for its
A

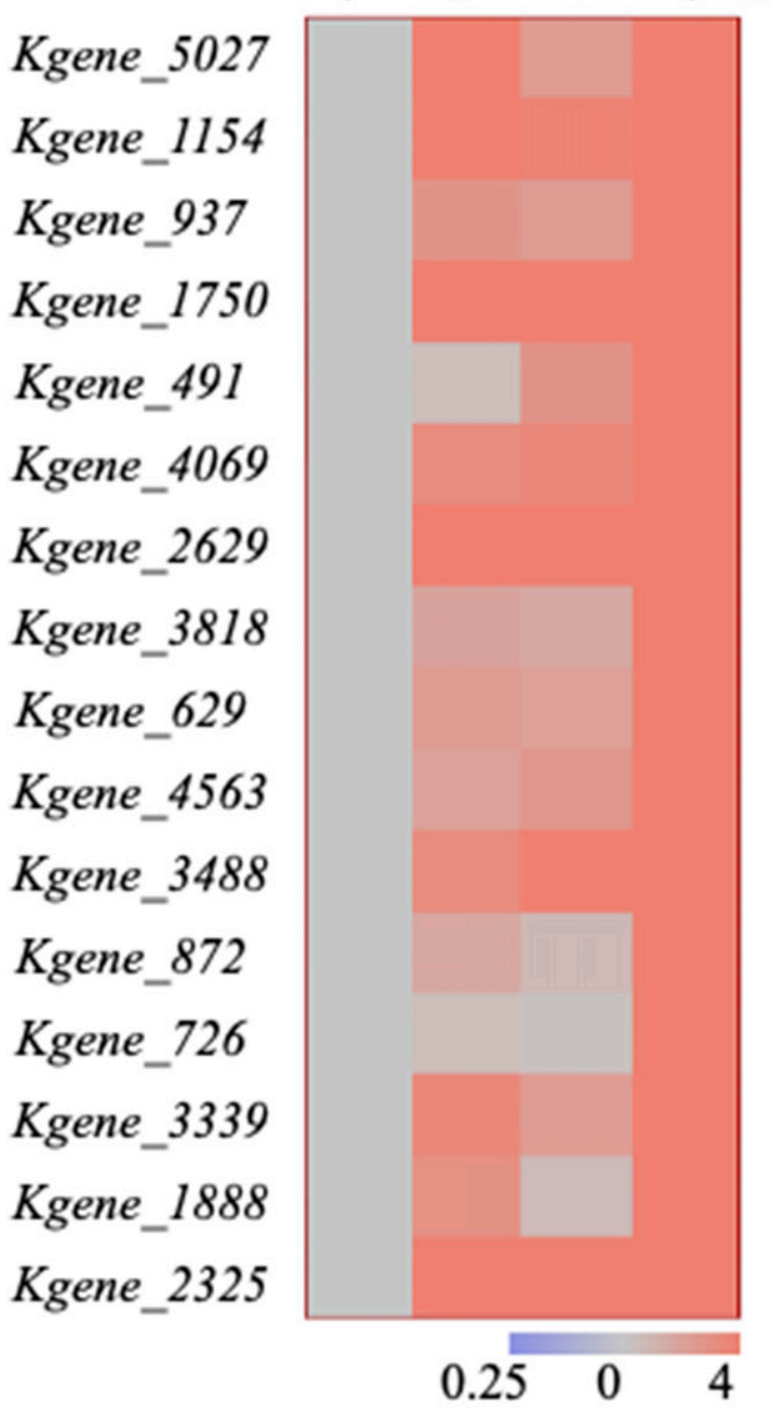

B

\begin{tabular}{ll}
\multicolumn{1}{c}{ Gene } & T3score \\
\hline Kgene_5027 & 0.00000 \\
Kgene_1154 & 0.04338 \\
Kgene_937 & 0.00000 \\
Kgene_1750 & 0.83140 \\
Kgene_491 & 0.15472 \\
Kgene_4069 & 0.00000 \\
Kgene_2629 & 0.00002 \\
Kgene_3818 & 0.00000 \\
Kgene_629 & 0.01348 \\
Kgene_4563 & 0.00000 \\
Kgene_3488 & 0.00119 \\
Kgene_872 & 0.00000 \\
Kgene_726 & 0.00000 \\
Kgene_3339 & 1.00000 \\
Kgene_1888 & 0.00000 \\
Kgene_2325 & 0.55888 \\
\hline
\end{tabular}

C

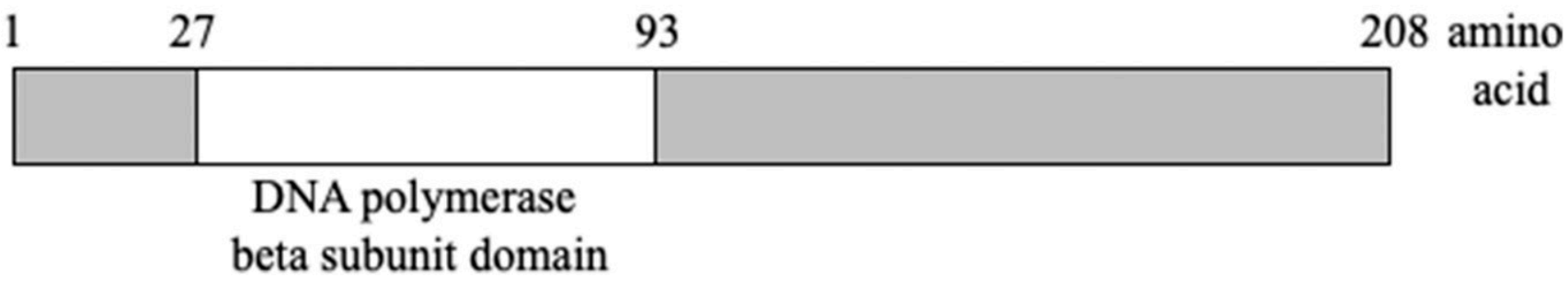

Fig. 4. Identification of $A K S F 1$ as an ETS-related effector-encoding gene. A, Expression patterns of $16 \mathrm{~K} 1$-genes after K1 inoculation to cultured rice cells. B, Prediction of bacterial protein secretion using EffectiveT3 software. C, Schematic drawing of AKSF1. White box indicates the domain with $14 \%$ identity to the N-terminal region of Escherichia coli DNA polymerase beta subunit. 
activity; since calmodulin is only present in eukaryotic cells, CyaA is only active in eukaryotic cells. Thus, accumulation of the Cya product cAMP (cyclic adenosine monophosphate) in inoculated plant tissues can be used to report type III effector delivery into plant cells (Casper-Lindley et al. 2002; Schechter et al. 2004). We therefore determined if cAMP accumulates in cultured rice cells following inoculation with either $K \Delta T 3 S S$ expressing AKSF1-CyaA or K1 expressing AKSF1-CyaA. cAMP was extracted from cultured rice cells $9 \mathrm{~h}$ postinoculation and was quantified using an enzyme immunoassay. High levels of cAMP accumulation were observed in cultured rice cells inoculated with AKSF1-CyaA expressing K1, while no accumulation of cAMP was detected in cultured rice cells inoculated with AKSF1-CyaA expressing KAT3SS (Fig. 5A). The differential accumulation of cAMP indicates that AKSF1 is secreted through T3SS into rice cells.

To determine AKSF1 localization after its transfer into rice cells, we cloned an AKSF1-Venus gene fusion into an expression plasmid and transformed cultured rice cells. Bright green Venus-derived signals were observed in both the cytoplasm and nucleus of rice protoplasts (Fig. 5B). AKSF1-Venus is a relatively small fluorescent protein that can pass freely through the nuclear pore. Hence, AKSF1 may be located mainly in the cytoplasm.

\section{AKSF1 functions as an ETS effector.}

To determine whether AKSF1 functions as an ETS effector, $A K S F 1$ was disrupted $(S F 1 D M)$ by inserting the pCR-Blunt vector into the $A K S F 1$ locus. Additionally, $A K S F 1$ was subsequently deleted $(K \Delta S F 1)$ by homologous recombination following pCR-Blunt insertion. Cultured rice cells were inoculated with either the K1 strain, $S F 1 D M, K \Delta S F 1$, or $K \Delta T 3 S S$ for $3 \mathrm{~h}$ before being treated with $100 \mathrm{nM}$ flagellin. When N1141 flagellin was added to cultured rice cells preinoculated with either SFIDM or $K \Delta S F 1$ for $1 \mathrm{~h}$, the amount of $\mathrm{H}_{2} \mathrm{O}_{2}$ generated was more than seven times that of cultured rice cells that were preinoculated with $\mathrm{K} 1$. Interestingly, the amount of $\mathrm{H}_{2} \mathrm{O}_{2}$ generated by $S F 1 D M$ - or $K \Delta S F 1$-inoculated cultured rice cells was almost the same as that by $K \Delta T 3 S S$-inoculated rice cells (Fig. 6A), indicating that the loss of the ability to suppress $\mathrm{H}_{2} \mathrm{O}_{2}$ generation in T3SS-deficient $\mathrm{K} 1$ mutant is caused by AKSF1 deficiency.

To determine the role of AKSF1 on flagellin-induced callose deposition, $S F 1 D M, K \Delta S F 1$, or $K \Delta T 3 S S$-inoculated cultured rice cells were treated with $200 \mathrm{nM}$ flagellin. Aniline blue staining to visualize callose showed that about three times the amount of callose was observed in cultured rice cells inoculated with $S F 1 D M, K \Delta S F 1$, or $K \Delta T 3 S S$, as compared with cultured rice cells inoculated with the $\mathrm{K} 1$ strain (Fig. 6B). Quantification of $P A L$ in flagellin-treated cultured rice cells showed that the $P A L$ expression level was about 10 times higher in cultured rice cells inoculated with either SF $1 D M, K \Delta S F 1$, or $K \Delta T 3 S S$ than in cells inoculated with the K1 strain (Fig. 6C). Similarly, OsWRKY70 mRNA levels in rice cells preinoculated with $S F 1 D M, K \Delta S F 1$, or $K \Delta T 3 S S$ were between three- to fourfold higher than in rice cells preinoculated with K1. (Fig. 6D). Interestingly, $\mathrm{H}_{2} \mathrm{O}_{2}$ generation and callose deposition induced by the flagellin in $S F 1 D M-, K \Delta S F 1$-, or $K \Delta T 3 S S$-preinoculated rice cells were slightly lower than those in water-pretreated cultured rice cells (Fig. 6A and B). In contrast, expression levels of $P A L$ and $O S W R K Y 70$ in SF1DM-, KASF1-, or $K \Delta T 3 S S$-preinoculated rice cells were higher than those in water-pretreated rice cells (Fig. 6C and D).

To determine the involvement of AKSF1 on downstream signaling events following flagellin recognition, MAPK activation by flagellin in $\mathrm{K} 1-, K \Delta T 3 S S$-, or $S F 1 D M$-preinoculated cultured rice cells. We previously reported that the activation of multiple MAPKs by the flagellin or CD2-0 in cultured rice cells was detected by an anti-p44/42-ERK antibody (Katsuragi et al. 2015). Therefore, cultured rice cells inoculated with $\mathrm{K} 1$, $K \Delta T 3 S S$, or SF1DM were treated with flagellin, and activated MAPKs were detected using an anti-p44/42-ERK antibody. The activation of two MAPKs were observed 5 and 10 min after flagellin treatment in water-pretreated cultured rice cells. The activation of MAPKs by flagellin treatment was decreased by preinoculation with the $\mathrm{K} 1$ strain, and the activation of the lower MAPK was not detected. By contrast, the two MAPKs were clearly activated in cultured rice cells inoculated with $K \Delta T 3 S S$ or SF1DM after the flagellin treatment (Fig. 6E), suggesting that AKSF1 also interferes with downstream signaling events following flagellin recognition.

To confirm the involvement of AKSF1 in the PTI suppression, we generated three complementary mutants, $K \Delta S F 1 / S F 1$ (reintroduction of the AKSF1 into the genome), KASF1/VSF1 (introduction of vector carrying $A K S F 1$ gene region into the genome), $K \Delta S F 1 / F p S F 1 C y a A$ (introduction of vector carrying $A K S F 1-C y a A$ regulated by a flagellin promoter). Cultured rice cells were inoculated with the $\mathrm{K} 1, K \Delta S F 1, K \Delta S F 1 / S F 1$, $K \Delta S F 1 / V S F 1$, or $K \Delta S F 1 / F p S F 1 C y a A$ for $3 \mathrm{~h}$ and were then treated with $100 \mathrm{nM} \mathrm{N} 1141$ flagellin.

The greatest amount of $\mathrm{H}_{2} \mathrm{O}_{2}$ generation was observed $1 \mathrm{~h}$ after treatment in water-pretreated rice cells, while $\mathrm{H}_{2} \mathrm{O}_{2}$ generation in $K \Delta S F 1 / S F 1$-, $K \Delta S F 1 / V S F 1$-, and $K \Delta S F 1 / F p S F 1 C y a A$ pretreated cultured rice cells were reduced to an extent similar to that in $\mathrm{K} 1$-pretreated rice cells (Fig. 6F). All these experimental data indicate that AKSF1, which translocates from K1 cells into rice cells, suppresses PTI responses induced by N1141 flagellin and functions as an ETS effector.

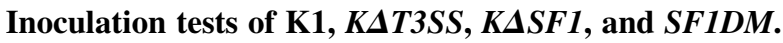

To clarify the role of AKSF1 in host plant infection, inoculation tests using $\mathrm{K} 1, K \Delta T 3 S S, K \Delta S F 1$, and $S F 1 D M$ were
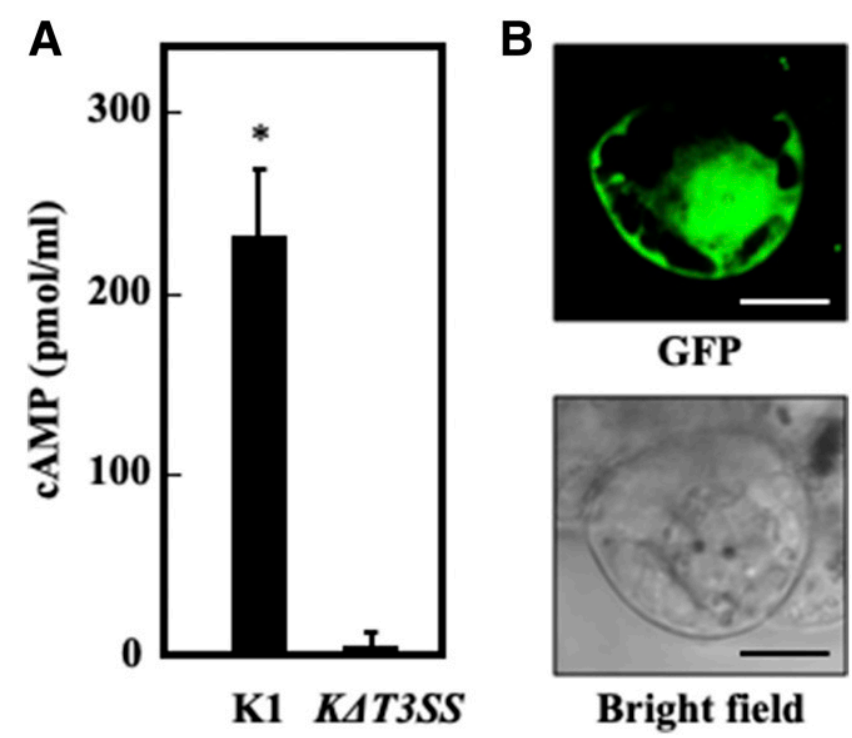

Fig. 5. Secretion of AKSF1 protein into rice cells. A, Cya translocation assay of AKSF1. The Acidovorax avenae $\mathrm{K} 1$ strain and $K \Delta T 3 S S$ transformed with a $\mathrm{pBBR} 1 T p$ plasmid expressing the AKSF1-CyaA fusion protein were inoculated into cultured rice cells, and $10 \mathrm{~h}$ after inoculation, cAMP concentration was measured. Bars indicate the standard deviation of three independent experiments. Asterisk indicates significant differences $(t$ test, $P<0.05)$. B, Subcellular localization of AKSF1-Venus fusion protein after $6 \mathrm{~h}$ transformation in cultured rice cells. Venus fused to the $\mathrm{N}$-terminus of AKSF1. Top panel shows a representative GFP image and bottom panel shows a representative bright-field image. Scale bars indicate $20 \mu \mathrm{m}$. 
performed. Brown stripe symptoms were observed in rice 4 days after $\mathrm{K} 1$ inoculation (Fig. 7A). When rice was inoculated with $K \Delta S F 1$ or $S F 1 D M$, brown stripe symptoms decreased to about $40 \%$ (Fig. 7B). In contrast, $K \Delta T 3 S S$ caused few brown stripe symptoms (Fig. 7A and B).

We next tested for the presence of inoculated bacteria by measuring internal bacterial load. When K1 wild type $\left(1 \times 10^{6}\right.$ colony-forming units [CFU] per microliter) was inoculated into rice, the number of $\mathrm{K} 1$ cells reached $7 \times 10^{7} \mathrm{CFU}$ per plant 4 days after inoculation (Fig. 7C). In rice plants inoculated with $K \Delta S F 1$ and $S F 1 D M$, the number of each bacterial strain was $4 \times 10^{7} \mathrm{CFU}$ per plant 4 days after inoculation. No remarkable increase in the number of $K \Delta T 3 S S$ cells was observed 4 days after inoculation (Fig. 7C). These observations, together with the lesion formation data, indicate that the absence of $A K S F 1$ genes results in a decrease in infectivity and reduction of disease symptoms in K1 strain.

\section{DISCUSSION}

In this study, we showed that the insertion of transposons into 68 genes reduces the ability to suppress PTI. A similar approach has been reported to have identified effector proteins with the ability to suppress PTI. In a screen based on transient expression of 22 putative effector-encoding genes from $P$. syringae pv. tomato DC3000 in Nicotiana benthamiana, seven proteins were found to suppress flg22-triggered $\mathrm{H}_{2} \mathrm{O}_{2}$ generation as well as expression of PTI-related genes (Gimenez-Ibanez et al. 2018). Transient expression of 61 genes from $R$. solanacearum RS1000 in N. benthamiana leaves to
A
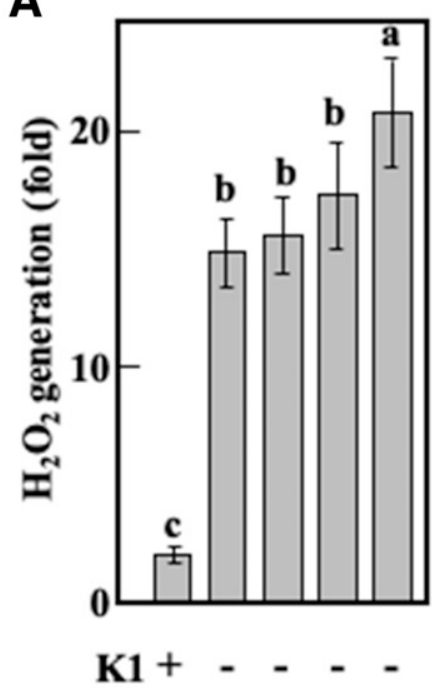

B

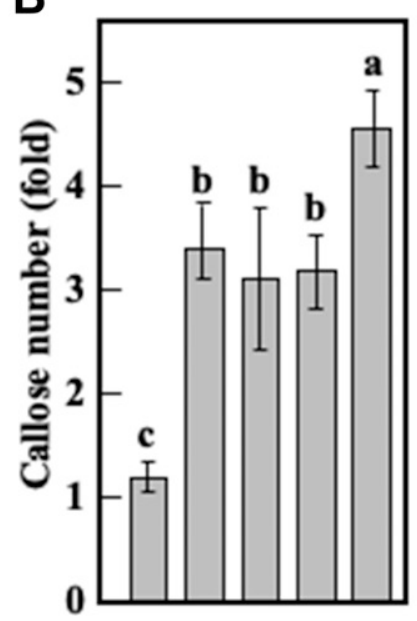

$\mathrm{K1}+$ - - - -
C

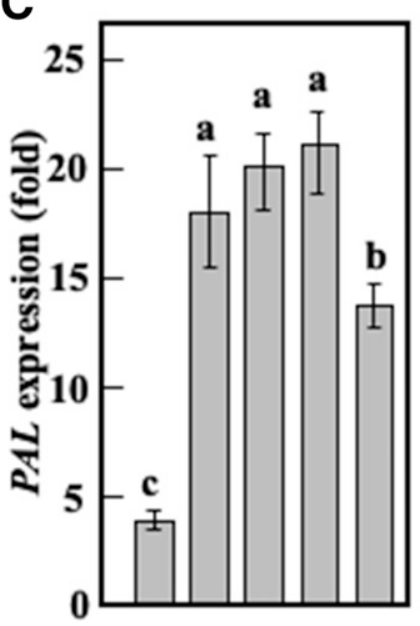

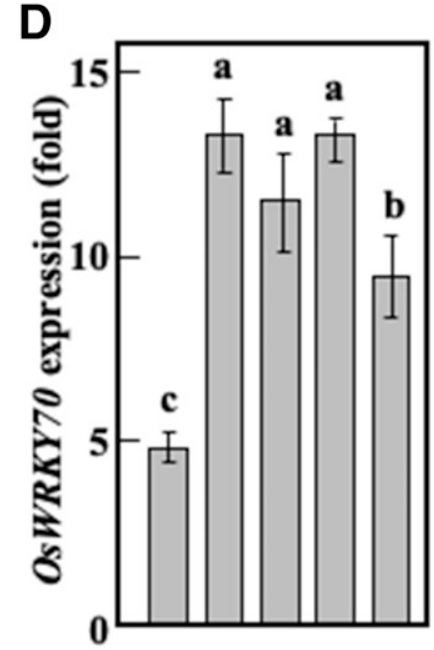

$$
\mathrm{K1}+\text { - - - - }
$$

SFIDM - + - -

KAT3SS - - - + -

Fla +++++ Fla +++++

E

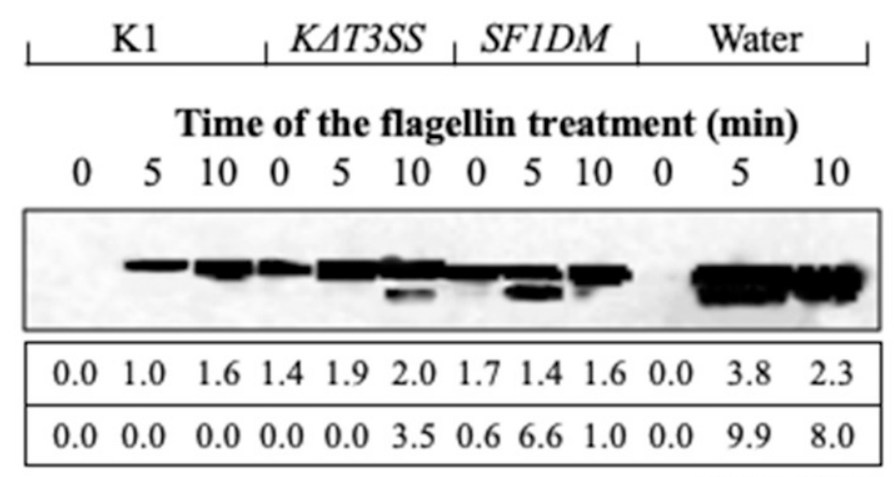

$\alpha$-p44/42-ERK

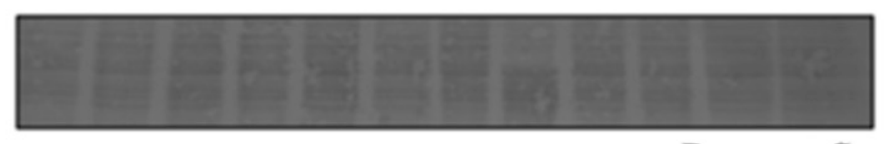

Ponceau-S

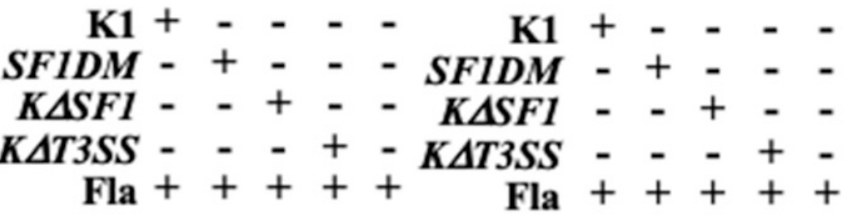

$\mathbf{F}$

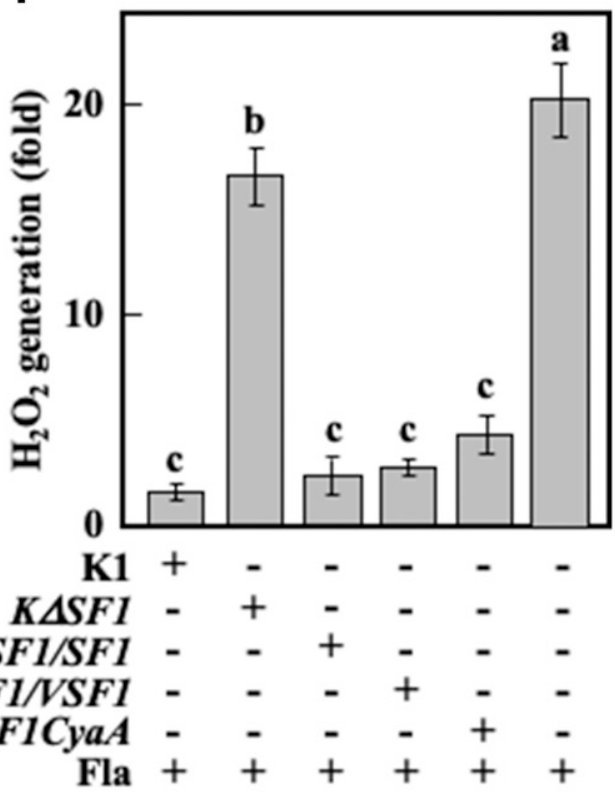


determine their ability to suppress flg22-induced ROS generation revealed that 11 proteins strongly suppressed and five proteins moderately suppressed the flg22-triggered ROS burst (Nakano and Mukaihara 2019). Our finding together with previous studies suggested that multiple proteins in the A. avenae $\mathrm{K} 1$ strain may be involved in suppressing plant PTI responses.

The amount of $\mathrm{H}_{2} \mathrm{O}_{2}$ generated by SF1DM- or $K \Delta S F 1$-inoculated cultured rice cells was almost the same as that in $K \Delta T 3 S S$-inoculated rice cells (Fig. 6A). Similar results have been observed for flagellin-induced callose deposition (Fig. 6B) and flagellin-induced upregulation of $P A L$ and $O s W R K Y 70$ (Fig. 6C and D). These results suggest that AKSF1 may be the major effector that inhibits the PTI responses induced by the flagellin. Interestingly, the expression levels of $P A L$ and OsWRKY70 in KAT3SS-inoculated rice cells treated with the flagellin were higher than that in the flagellin-treated control cells (Fig. 3C and D). In addition, the expression levels of two genes in K1-inoculated rice cells were about five times higher than those in the control cells. It appears that the $\mathrm{K} 1$ or $K \Delta T 3 S S$ strains possess a PAMP-like substance other than K1 flagellin because K1 flagellin did not cause the PTI responses (Che et al. 2000). $\mathrm{H}_{2} \mathrm{O}_{2}$ generation and callose deposition in $\mathrm{K} 1-$ preinoculated rice cells were similar to those in the control cells, suggesting that this PAMP-like substance induces expression of $P A L$ and $O s W R K Y 70$ but not $\mathrm{H}_{2} \mathrm{O}_{2}$ generation and callose deposition. This PAMP-like substance appears to cause MAPK activation, because clear activation of MAPK was detected in $K \Delta T 3 S S$ - or $S F 1 D M$-preinoculated cultured rice cells before the flagellin treatment (Fig. 6E). Furthermore, the activation of MAPK was not observed in K1-preinoculated rice cells before flagellin treatment, suggesting that AKSF1 may suppress the MAPK activation by the PAMP-like substance. Characterization of such PAMP-like substance remains as a future research topic.

The perception of flg22 by FLS2 causes rapid production of high levels of ROS, a phenomenon that is dependent on the respiratory burst oxidase homolog $(\mathrm{RBOH})$ family. A two-step activation model for $\mathrm{RBOH}$ during immunity has been proposed based on previous studies. Following flagellin perception, FLS2 and its coreceptor BAK1, directly phosphorylate and activate Botrytis-induced kinase 1 (BIK1). Phosphorylation of BIK1 enhances the affinity to $\mathrm{RBOH}$ and promotes phosphorylation of RBOH at several different sites (Li et al. 2014). BIK1-mediated phosphorylation could result in increased $\mathrm{Ca}^{2+}$ binding affinity for EF-hand motifs in $\mathrm{RBOH}$ and increased accessibility for $\mathrm{Ca}^{2+}$-dependent protein kinase (CPK)mediated phosphorylation (Kadota et al. 2015). On the other hand, the binding of flg22 to FLS2 activates one or more $\mathrm{Ca}^{2+}$ channels and induces $\mathrm{Ca}^{2+}$ influx either directly or indirectly. Increased intracellular $\mathrm{Ca}^{2+}$ promotes $\mathrm{Ca}^{2+}$ binding to an $\mathrm{EF}$ hand motif in $\mathrm{RBOH}$ and activates CPKs, which in turn phosphorylates $\mathrm{RBOH}$. The $\mathrm{H}_{2} \mathrm{O}_{2}$ generated may also cause further activation of one or more $\mathrm{Ca}^{2+}$ channels, resulting in complete activation of $\mathrm{Ca}^{2+}$ signaling and $\mathrm{Ca}^{2+}$-based regulation of RBOH (Kimura et al. 2020). We previously reported that treating rice cells with $\mathrm{N} 1141$ flagellin caused a rapid increase in $\mathrm{Ca}^{2+}$ concentration and that the induction of $\mathrm{H}_{2} \mathrm{O}_{2}$ generation caused by flagellin requires $\mathrm{Ca}^{2+}$ influx into rice cells (Kaneda et al. 2009). Furthermore, we also reported that $\mathrm{H}_{2} \mathrm{O}_{2}$ induced by N1141 flagellin was generated by rice NADPH oxidases, such as OsrbohA and OsrbohE (Yoshie et al. 2005). These results indicate that AKSF1 causes ETS by inhibiting OsrbohA and OsrbohE activation. However, no direct interaction between AKSF1 and either OsrbohA or OsrbohE was observed, suggesting that suppression of flagellin-triggered $\mathrm{H}_{2} \mathrm{O}_{2}$ generation by AKSF1 may be caused by inhibiting intracellular $\mathrm{Ca}^{2+}$ influx. Further studies about the effect of AKSF1 on $\mathrm{Ca}^{2+}$ influx following flagellin recognition will be needed.

AKSF1 shows $14 \%$ identity to the $\mathrm{N}$-terminal region of DNA polymerase beta in Escherichia coli. Motif analysis using PSORT and cNLS Mapper showed that AKSF1 was localized mainly to the cytosol. In fact, when AKSF1-Venus was expressed in rice cells, Venus-derived fluorescence was observed in both the nucleus and cytosol. Since the molecular mass of the AKSF1-Venus fusion protein is $53 \mathrm{kDa}$, it can diffuse into the nucleus without a nuclear localization signal (NLS). These results together with the lack of NLSs within AKSF1 suggest that AKSF1 is located mainly in the cytosol in rice cells. If PTI suppression by AKSF1 requires the DNA polymerase function, AKSF1 must be localized to the nucleus in rice cells. Although AKSF1 shows sequence homology with the N-terminal region of DNA polymerase beta subunit, DNA polymerase-like functions may not be required for PTI suppression induced by flagellin.

The full-length amino acid sequence of AKSF1 shares $43 \%$ amino acid sequence identity with DUF4935. The DUF4935 superfamily that is uncharacterized protein is mostly found in several bacterial species and consists of around 350 amino acid residues in length. Recently, DUF4935 was classified, as a PIN

Fig. 6. Suppression ability of flagellin-induced pathogen-associated molecular pattern-triggered immunity in AKSF1 insertion (SF1DM) and AKSF1 deletion $(K \Delta S F 1)$ mutants. A, Suppression of flagellin-induced $\mathrm{H}_{2} \mathrm{O}_{2}$ generation in cultured rice cells by $S F 1 D M$ or $K \Delta S F 1$. Cultured rice cells were either inoculated with the K1 strain, $S F 1 D M, K \Delta S F 1$, or $K \Delta T 3 S S$ (+) or were left uninoculated (-) for $3 \mathrm{~h}$ before being treated with $100 \mathrm{nM}$ flagellin. The vertical axis represents fold change relative to the amount of $\mathrm{H}_{2} \mathrm{O}_{2}$ in control cells (without $\mathrm{K} 1$ strain inoculation and without flagellin treatment). Error bars indicate the standard deviation of five independent experiments. Lower case letters above bars indicate significant differences according to the Tukey-Kramer test $(P<0.05)$. B, Suppression of flagellin-induced callose deposition in cultured rice cells by SF1DM or KASF1. Cultured rice cells were either inoculated with the K1 strain, $S F 1 D M, K \Delta S F 1$, or $K \Delta T 3 S S$ (+) or were left uninoculated (-) for $3 \mathrm{~h}$ before being treated with $200 \mathrm{nM}$ flagellin. The vertical axis represents fold change relative to the amount of callose deposition in control cells (without K1 strain inoculation and without flagellin treatment). Error bars indicate the standard deviation of three independent experiments. Lower case letters above bars indicate significant differences according to the Tukey-Kramer test $(P<0.05)$. $\mathbf{C}$ and D, Suppression of flagellin-induced $P A L$ (C) or $O s W R K Y 70$ (D) expression in cultured rice cells by $S F 1 D M$ or $K \Delta S F 1$. Cultured rice cells were either inoculated with the K1 strain, $S F 1 D M, K \Delta S F 1$, or $K \Delta T 3 S S$ (+) or were left uninoculated (-) for $3 \mathrm{~h}$ before being treated with $100 \mathrm{nM}$ flagellin. After $1 \mathrm{~h}$, the amount of either PAL or OsWRKY70 messenger RNA (mRNA) was determined by quantitative reverse-transcription PCR. The vertical axis represents fold change relative to the amount of $P A L$ or $O s W R K Y 70$ mRNA in control cells (without K1 strain inoculation and without flagellin treatment). Error bars indicate the standard deviation of five independent experiments. Lower case letters above bars indicate significant differences according to the Tukey-Kramer test $(P<$ 0.05). E, Effect of SF1DM inoculation on phosphorylation of mitogen-activated protein kinases (MAPKs) in flagellin-treated cultured rice cells. Cultured rice cells were inoculated with either the K1 strain, $K \Delta T 3 S S$, or SF1DM before being treated with $100 \mathrm{nM}$ flagellin. Phosphorylation of MAPK (top) and loading control (bottom) are shown. Values at the bottom of the top panel show the relative phosphorylated protein levels of $44 \mathrm{~K}$ (top) and 33K (bottom). F, Complementation of suppression ability of flagellin-induced $\mathrm{H}_{2} \mathrm{O}_{2}$ generation by expression of $A K S F 1$ in $K \Delta S F 1$. Cultured rice cells were either inoculated with the K1 strain, $K \Delta S F 1, K \Delta S F 1 / S F 1, K \Delta S F 1 / V S F 1$, or $K \Delta S F 1 / F p S F 1 C y a A(+)$ or were left uninoculated (-) for $3 \mathrm{~h}$ before being treated with $100 \mathrm{nM}$ flagellin. The vertical axis represents fold change relative to the amount of $\mathrm{H}_{2} \mathrm{O}_{2}$ in control cells (without $\mathrm{K} 1$ strain inoculation and without flagellin treatment). Error bars indicate the standard deviation of five independent experiments. Lower case letters above bars indicate significant differences according to the Tukey-Kramer test $(P<0.05)$. 
domain family member that belongs to the metal-dependent nucleases superfamily, by transitive sequence searches using highly sensitive methods for remote homology detection (Matelska et al. 2017). Proteins with PIN domains are involved in important cellular processes including mRNA degradation, transcription regulation, DNA replication and repair, and noncoding RNA maturation. Because AKSF1 bears a high degree of similarity to DUF, AKSF1 may have nuclease activity. Several studies revealed that T3SS effector proteins suppress PTI using their enzymatic activity. For example, HopAO1 from $P$. syringae is classified as a tyrosine phosphatase and suppresses FLS2-mediated PTI responses using its phosphatase activity (Macho et al. 2014). Another example is the E3 ubiquitin ligase AvrPtoB from $P$. syringae, which suppresses flg22triggered immunity by ubiquitinating FLS2, thereby triggering its degradation (Cheng et al. 2011; Gimenez-Ibanez et al. 2009; Göhre et al. 2008). However, there is no report that flagellintriggered immunity is suppressed via nuclease activity. Uncovering the mechanism of PTI suppression by AKSF1 will provide insights into a novel mechanism of ETS induction.

\section{MATERIALS AND METHODS}

Plants and bacteria.

Suspension cultures of rice cells, line Oc (Baba et al. 1986), were grown at $30^{\circ} \mathrm{C}$ under light irradiation (Baba et al. 1986). The cells were diluted in fresh medium every week, and all experiments were performed 4 days after transfer. Acidovorax avenae N1141 (MAFF 301141) and K1 (MAFF 301755) were used as previously described (Che et al. 2000; Kadota et al. 1996). Rice (Oriza sativa L. cultivar Kinmaze) was grown for 3 weeks in a growth chamber with a 16-h day $\left(200 \mu \mathrm{E} \mathrm{m}^{-2} \mathrm{~s}^{-1}\right.$ at $\left.30^{\circ} \mathrm{C}\right)$ and 8 -h night $\left(28^{\circ} \mathrm{C}\right)$ cycle.

\section{Purification of flagellin from $A$. avenae N1141.}

Flagellin was purified as previously described (Che et al. 2000), with the following modifications. The A. avenae N1141 strain was grown for $24 \mathrm{~h}$ in Luria-Bertani (LB) medium at $30^{\circ} \mathrm{C}$ on a rotary shaker. Cells were collected by centrifugation at $6,000 \times g$ for $20 \mathrm{~min}$ at $4^{\circ} \mathrm{C}$. The pellets were washed with TBS buffer (25 mM Tris-HCl, pH7.4, $137 \mathrm{mM} \mathrm{NaCl}$, and

\section{A}
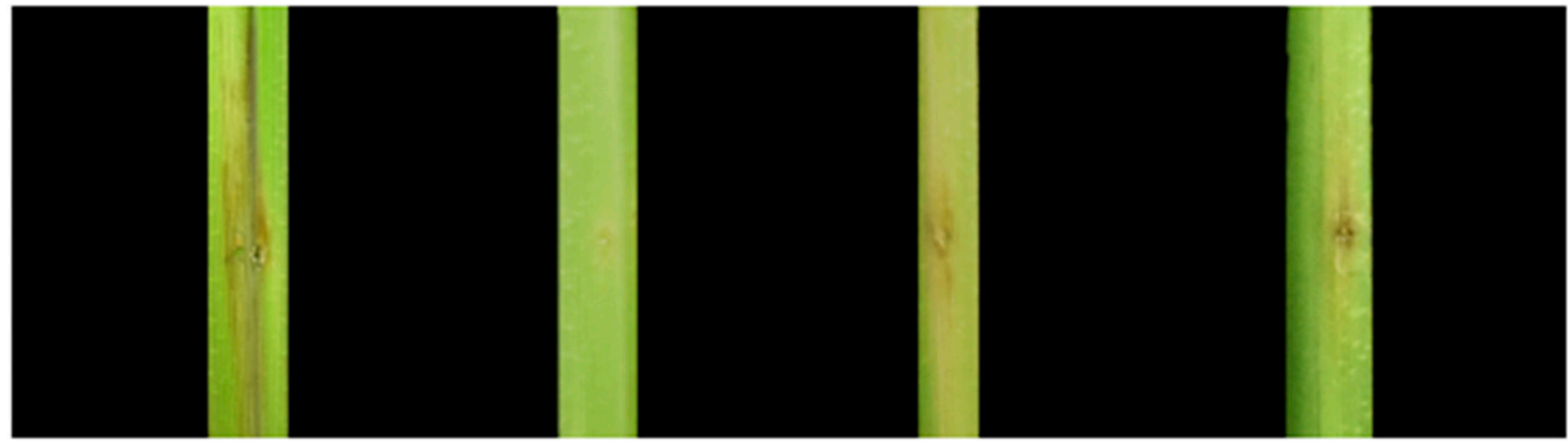

K1

KAT3SS

KASFI

SFIDM

B

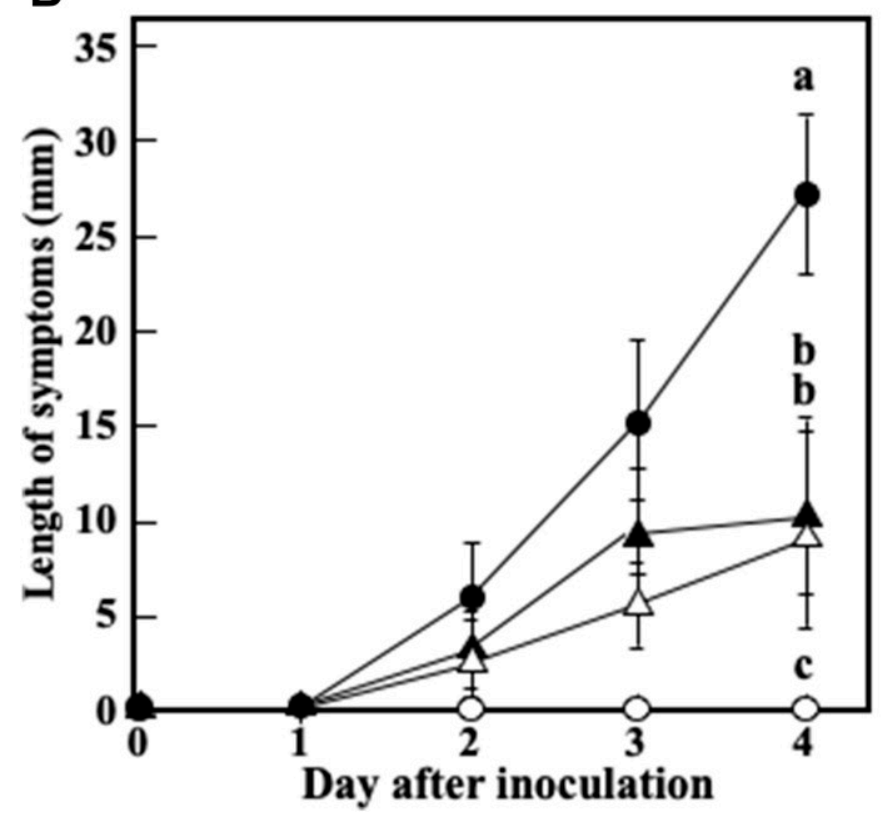

C

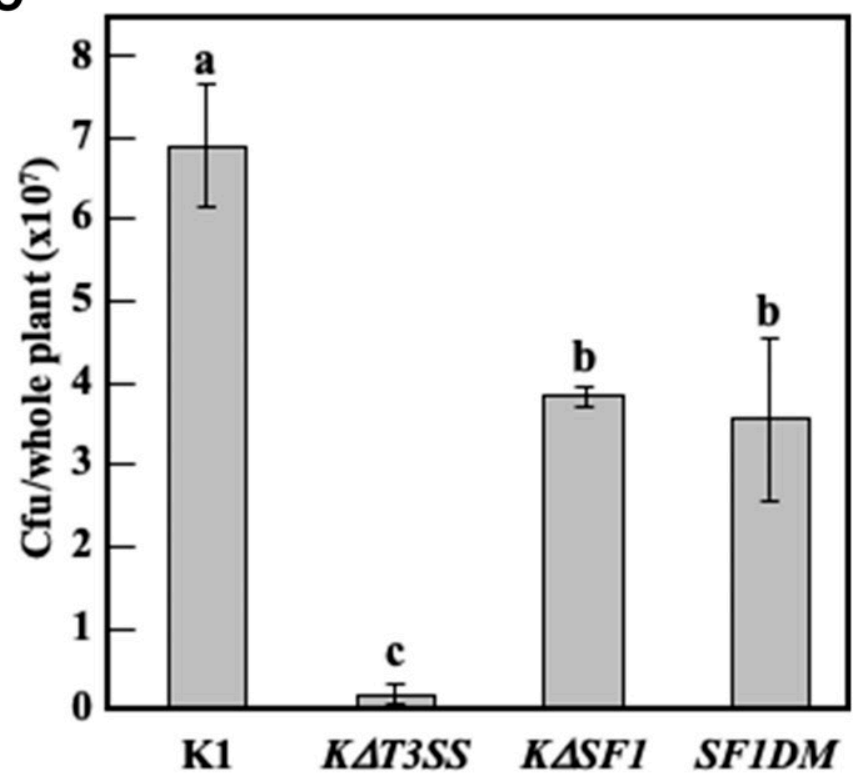

Fig. 7. Inoculation tests of $\mathrm{K} 1, K \Delta T 3 S S, K \Delta S F 1$, and $S F 1 D M$ in rice. A, Brown stripe symptoms in rice 4 days after inoculation. B, Length of brown stripe symptoms in K1-inoculated rice (solid circle), $K \Delta T 3 S S$-inoculated rice (open circle), $K \Delta S F 1$-inoculated rice (solid triangle), and $S F 1 D M$-inoculated rice (open triangle). Bacterial strains $\left(1 \times 10^{6} \mathrm{CFU}\right)$ were inoculated into 21-day-old rice seedlings, using the single-needle method. Bars indicate standard deviation of three experiments. C, Number of bacterial cells in whole rice plants 4 days after inoculation. Bars indicate standard deviation of three experiments. Lower case letters above bars in $\mathrm{B}$ and $\mathrm{C}$ indicate significant differences according to the Tukey-Kramer test $(P<0.05)$. 
$2.68 \mathrm{mM} \mathrm{KCl}$ ), were collected by centrifugation, and were then resuspended in $90 \mathrm{ml}$ of TBS buffer. Flagella were removed from the cells by shearing for $3 \mathrm{~min}$ in a homogenizer (Ultra $\mathrm{F}$ Homogenizer HF-93-F; Taitec, Koshigaya, Japan). Intact cells and cellular debris were removed, using a two-step centrifugation procedure at $6,000 \times g$ for $30 \mathrm{~min}$ and $16,000 \times g$ for $60 \mathrm{~min}$ at $4^{\circ} \mathrm{C}$. The flagella were collected by ultracentrifugation at $200,000 \times g$ for $60 \mathrm{~min}$ at $4^{\circ} \mathrm{C}$. The pellets were resuspended in $1 \mathrm{ml}$ of distilled water and were centrifuged at $20,000 \times g$ for $5 \mathrm{~min}$ at $4^{\circ} \mathrm{C}$. After the supernatants were removed, the flagellin was stored at $-80^{\circ} \mathrm{C}$.

\section{$\mathrm{H}_{2} \mathrm{O}_{2}$ detection and quantification.}

$\mathrm{H}_{2} \mathrm{O}_{2}$ produced in the medium of cultured rice cells was monitored based on chemiluminescence due to the ferricyanide-catalyzed oxidation of luminol (5-amino-2,3 dihydro-1,4-phthalazinedione) (Schwacke and Hager 1992). Ten milligrams of cultured rice cells were transferred to fresh medium and were preincubated for $2 \mathrm{~h}$ at $30^{\circ} \mathrm{C}$. Cultured rice cells were inoculated with $1.0 \times 10^{8} \mathrm{CFU} / \mathrm{ml}$ of each bacteria and were incubated at $30^{\circ} \mathrm{C}$. The cultured rice cells were washed with $\mathrm{R} 2 \mathrm{~S}$ medium three times and were incubated with $100 \mathrm{nM} \mathrm{N} 1141$ flagellin at $30^{\circ} \mathrm{C}$ for the incubation periods after bacterial treatment. Following this incubation, $10 \mu \mathrm{l}$ of the medium was harvested, was added to $180 \mu \mathrm{l}$ of $50 \mathrm{mM}$ potassium phosphate buffer ( $\mathrm{pH} 7.9)$ containing $15.56 \mathrm{mM}$ potassium ferricyanide and $10 \mu \mathrm{l}$ of 1.1-mM luminol, and were immediately analyzed for chemiluminescence, using a Phelios (AB2350, ATTO, Tokyo).

\section{RNA isolation and qRT-PCR.}

Total RNA was isolated from cultured rice cells using RNeasy plant mini kit (Qiagen, Hilden, Germany) with DNase digestion according to manufacturer instructions. qRT-PCR was performed on an Opticon2 instrument (Bio-Rad, Hercules, CA, U.S.A.), using a GoTaq One-Step RT-qPCR kit (Promega, Madison, WI, U.S.A.), with the following gene-specific $P A L$ gene primers: forward, 5'-ACATCGGCAAGCTCATGTTC-3', reverse, 5'-CC CTTGAACCCGTAGTCCAA-3' and the following gene-specific OsWRKY70 gene primers: 5'-GGCGTCTCGTCCTCCGGGTT-3' and $5^{\prime}$-GTCGTAATCCAGCTGAACAA-3'. The mRNA levels were normalized based on reference genes $e l F-4 a$ and $18 S$ ribosomal RNA (rRNA) (Takai et al. 2008).

\section{Callose detection.}

Detection of callose deposition was performed as described previously (Katsuragi et al. 2015). Cultured rice cells were inoculated with $1.0 \times 10^{8} \mathrm{CFU} / \mathrm{ml}$ of each bacterial strain and were incubated for $3 \mathrm{~h}$ at $30^{\circ} \mathrm{C}$. The cultured rice cells were washed with R2S medium three times and were incubated with $200 \mathrm{nM} \mathrm{N} 1141$ flagellin at $30^{\circ} \mathrm{C}$ for $6 \mathrm{~h}$. After incubation, cultured rice cells were washed three times, using $100 \mathrm{mM}$ potassium phosphate buffer $(\mathrm{pH} \mathrm{8.0)}$, and were then fixed by Farmer's fixative at room temperature for $1 \mathrm{~h}$. After the fixation, cultured rice cells were washed three times with $100 \mathrm{mM}$ potassium phosphate buffer $(\mathrm{pH} 8.0)$ and were then stained by $100 \mathrm{mM}$ potassium phosphate buffer $(\mathrm{pH} 8.0)$ containing $0.1 \%$ aniline blue for $4 \mathrm{~h}$. Cultured rice cells were washed three times with $100 \mathrm{mM}$ potassium phosphate buffer ( $\mathrm{pH}$ 8.0) and callose deposition was observed using a fluorescence microscope (BX51; Olympus, Tokyo).

\section{Prediction of protein secretion.}

EffectiveT3 prediction (Arnold et al. 2009) was performed using the following parameters: EffectiveT3 Model 2.0, restriction value: selective ( $>0.9999)$, Classification module: Type III Effector prediction with plant set.

\section{RNA sequencing.}

K1 was cultured with cultured rice cells for $6 \mathrm{~h}$. The supernatant containing bacteria was collected at $0,2,4$, or $6 \mathrm{~h}$ postinfection and bacteria was collected by centrifugation at $6,000 \times$ $g$ for $5 \mathrm{~min}$ at $4^{\circ} \mathrm{C}$, after removing rice cells from cultured medium completely by cell strainer. The bacterial cells were frozen in liquid nitrogen and were kept in a $-80^{\circ} \mathrm{C}$ freezer until RNA extraction. Total RNA was isolated from bacterial cells using RNeasy plant mini kit (Qiagen) with DNase digestion according to manufacturer instructions. rRNA was removed from total RNA with Ribo-Zero rRNA removal kit (Illumina, San Diego, CA, U.S.A.). The sample was sent to Eurofins Genomics (Tokyo) for mRNA sequencing (125 bp paired-end reads) with Illumina HiSeq2500 (Illumina). To analyze RNAseq data, Subio Platform (Subio, Kagoshima, Japan) selected genes whose expression increased more than fivefold after bacterial inoculation and displayed the gene profiles as a heat map.

\section{Generation of K1 mutants.}

To generate the AKSF1-insertion mutant, the 40 to $378 \mathrm{bp}$ region of $A K S F 1$ was amplified by PCR using a specific primer set (5'-TATTCCGCCGCCACCATTTCC-3', 5'-AATGCCCGGC GATGTTAGTGC-3'). The PCR product was cloned into pCRblunt vector using Zero Blunt PCR cloning kit (Invitrogen, San Diego, CA, U.S.A.) and was transformed into K1 by electroporation. The transformed bacterial cells were plated on Pseudomonas $\mathrm{F}$ agar plates (containing $50 \mu \mathrm{g}$ of kanamycin per milliliter) and were incubated for $48 \mathrm{~h}$ at $30^{\circ} \mathrm{C}$. The resulting bacteria were designated SFIDM.

To generate the AKSF1-deleted mutant, upstream and downstream regions of $A K S F 1$ were PCR-amplified using two sets of specific primers (5'-CAGGTCGACTCTAGAAACAT CGAATTTATTACAGCAC-3', and 5'-TCAATCAATCGTAC ATCCAAAATAACTCGG-3', for the upstream region of $A K S F 1$, and 5'-TTGGATGTACGATTGATTGAAAAATATA ATTTAAAATATC-3' and 5'-CGGGGATCCTCTAGAGTGA AAGACATCCTGCGGAG-3', for the downstream region of $A K S F 1)$. Each of the amplified PCR products were diluted and mixed equally. The mixed PCR products were reamplified using the Kgene3339-UP-F and Kgene3339-DOWN-R primers. The PCR product was cloned into $\mathrm{pK} 18$ mobsacBTET linearized by Xba 1 using the Infusion cloning kit (Takara Bio, Shiga, Japan), and the resulting plasmid was designated pK18mobsacBTET/K $\Delta \mathrm{SF} 1$, which was electro-transformed into A. avenae $\mathrm{K} 1$. The bacterial cells were plated on LB agar plates (containing $20 \mu \mathrm{g}$ of tetracycline per milliliter) and were incubated for $48 \mathrm{~h}$ at $30^{\circ} \mathrm{C}$. For the second crossing-over event, the colonies were incubated in sucrose selection media (Pseudomonas $\mathrm{F}$ liquid medium containing $26 \%$ sucrose) for $72 \mathrm{~h}$ at $30^{\circ} \mathrm{C}$. This mutant was named $K \Delta S F 1$.

To generate $K \Delta S F 1 / S F 1, A K S F 1$ was PCR-amplified using a set of specific primers (5'-CAGGTCGACTCTAGAAACATCGAAT TTATTACAGCAC-3' and 5'-CGGGGATCCTCTAGAGTGAAAGACATCCTGCGGAG-3'). The PCR product was cloned into pK18mobsacBKm linearized by Xba1, using the Infusion cloning kit (Takara Bio), and the resulting plasmid was designated pK18mobsacBKm/AKSF1, which was electrotransformed into $K \Delta S F 1$. The bacterial cells were plated on LB agar plates (containing $50 \mu \mathrm{g}$ of kanamycin per milliliter) and were incubated for $48 \mathrm{~h}$ at $30^{\circ} \mathrm{C}$. For the second crossingover event, the colonies were incubated in sucrose selection media (Pseudomonas F liquid medium containing 27\% sucrose) for $72 \mathrm{~h}$ at $30^{\circ} \mathrm{C}$.

To generate $K \Delta S F 1 / V S F 1, A K S F 1$ including promoter and terminator regions was PCR-amplified using a set of specific primers (5'-TTTCCGGGATCACCCTGC-3' and $5^{\prime}$ CGGGAGCGCCAGTTTCAGCA-3'). The PCR product was 
cloned into pCR-blunt vector using Zero Blunt PCR cloning kit (Invitrogen) and was transformed into $K \Delta S F 1$ with electroporation. The transformed bacterial cells were plated on Pseudomonas $\mathrm{F}$ agar plates (containing $50 \mu \mathrm{g}$ of kanamycin per milliliter) and were incubated for $48 \mathrm{~h}$ at $30^{\circ} \mathrm{C}$.

To generate KASF1/FpSF1CyaA, flapro-AKSF1$C y a A / p B B R 1 T P$ was transformed into $K \Delta S F 1$ with electroporation. The transformed bacterial cells were plated on Pseudomonas $\mathrm{F}$ agar plates (containing $50 \mu \mathrm{g}$ of trimethoprim per milliliter) and were incubated for $48 \mathrm{~h}$ at $30^{\circ} \mathrm{C}$.

\section{Adenylate cyclase translocation assay.}

Transport of AKSF1 into rice cells via T3SS was examined by the adenylate cyclase translocation assay. The promoter region of flaA (336 bp) containing an additional 5'-terminal XbaI site and $3^{\prime}$-terminal HindIII site were PCR-amplified from the A. avenae N1141 genome using a specific primer set $\left(5^{\prime}\right.$ TCTAGAGGCGGAACTCCTGCG-3' and 5'-AAGCTTCA TTGCAAATCTCCTGAAAAGAAC- $3^{\prime}$ ) and were cloned into $p G E M-T$. The plasmid was digested by $X b a \mathrm{I}$ and HindIII and was cloned into $p B B R I T p$ and the produced plasmid was named flapro/pBBRITp. CyaA was PCR-amplified using primer set 5' AAGCTTCAGCAATCGCATCAGGC-3' and 5'-GGTACCTCAGCTGTCATAGCCGGA-3' and was cloned into $p G E M-T$. The plasmid was digested by HindIII and $K p n I$ and was cloned into flapro/pBBRITp, the produced plasmid was named flaproCyaA/pBBRITP. AKSF1 was PCR-amplified from K1 genome using a specific primer set (5'-TTTGCAATGAAGCTTATGTACTCATCCGTACAATTCGTAG-3' and 5'-CGATTGCTGAAGCTTATCATCTTGGTAATCTGGGTTATT-3'). The PCR product was cloned into flapro-CyaA/pBBRITP linearized by HindIII, using the In-fusion HD cloning kit (Takara Bio), and the plasmid was named flapro-AKSF1-CyaA/pBBRITP. flapro$A K S F 1-C y a A / p B B R 1 T P$ was transformed into $\mathrm{K} 1$ or $K \Delta T 3 S S$ by electroporation. Cultured rice cells were inoculated with $1.0 \times$ $10^{8} \mathrm{CFU} / \mathrm{ml}$ of $\mathrm{K} 1$ carrying $A K S F 1-C y a A$ vector and were incubated for $10 \mathrm{~h}$ at $30^{\circ} \mathrm{C}$. After incubation, cultured rice cells were washed three times with distilled water and were resuspended in $200 \mu \mathrm{l}$ of distilled water. The cells were boiled for $5 \mathrm{~min}$, were smashed with zirconia beads, using Bead Smash 12 (Wakenyaku, Kyoto, Japan) at 5,000 rpm for $5 \mathrm{~min}$, and were then centrifuged at $1,500 \times g$ for $10 \mathrm{~min}$ at $4^{\circ} \mathrm{C}$. The concentration of cAMP in the supernatant was measured using the cAMP EIA kit (Cayman Chemical, Ann Arbor, MI, U.S.A.).

\section{Subcellular localization of AKSF1.}

$A K S F 1$ were PCR-amplified using a specific primer set (5'CACCATGTACTCATCCGTACAATTCGTAG- ${ }^{\prime}$, and $5^{\prime}$-ATC ATCTTGGTAATCTGGGTTATT- $\left.3^{\prime}\right)$. The PCR products were cloned into pENTR-D-TOPO (Thermo Fisher Scientific, Waltham, MA, U.S.A.). The AKSF1 region within the plasmid was introduced into the $G W$-venus/pbI221 vector (Ootsubo et al. 2016), using the Gateway Vector Conversion System. The resulting vector was designated AKSF1Venus/pBI221.

Cultured rice cells were harvested and were plated on $\mathrm{R} 2 \mathrm{O}$ ager at $30^{\circ} \mathrm{C}$ for $3 \mathrm{~h}$. The $A K S F 1$-Venus $/ p B I 221$ vector was introduced into cultured rice cells using particle bombardment (Bio-Rad). After a 6-h incubation at $30^{\circ} \mathrm{C}$, Venus fluorescence was observed with the confocal laser scanning microscope (FV1000; Olympus).

\section{MAPK assay.}

Detection of phosphor-MAPK was performed as described previously (Katsuragi et al. 2015), with the following modifications. Phosphorylation of MAPK was determined in crude protein extracts from each bacterial strain-preinoculated cultured rice cells treated with $100 \mathrm{nM}$ flagellin for 5 or $10 \mathrm{~min}$ and were prepared as described previously (Romeis et al. 1999). The protein concentration was determined using the Pierce $660 \mathrm{~nm}$ protein assay reagent (Thermo Fisher) with bovine serum albumin as a standard. Crude extracts $(10 \mu \mathrm{g}$ of total protein per lane) were separated on a $12.5 \%$ sodium dodecyl sulfate gel and proteins were transferred onto nitrocellulose membrane (GE Healthcare, Chicago) by semidry electroblotting (Bio-Rad). Phosphorylated MAPK were detected by overnight incubation with anti-phospho-p42/44 MPK (Erk1/2) (Thr202/Tyr204) antibodies (1:2,000) (Cell Signaling Technology), followed by incubation with antirabbit immunoglobulin $\mathrm{G}(\mathrm{H}+\mathrm{L}$ chain)-horseradish peroxidase secondary antibodies (MBL, Nagoya, Japan) for $1 \mathrm{~h}$. The signals were visualized using the ECL Prime Western blotting detection system (GE Healthcare), following manufacturer instructions.

\section{Inoculation test.}

Inoculation of $A$. avenae was performed as described previously (Kondo et al. 2017), with the following modifications. The bacteria were suspended in sterilized distilled water $(1 \times$ $\left.10^{6} \mathrm{CFU} / \mu \mathrm{l}\right)$. A $1-\mu \mathrm{l}\left(10^{6} \mathrm{CFU}\right)$ drop of the bacterial suspension medium was formed on the end of a needle and, then, the sheaths of 3-week-old seedlings were pricked at a point $3 \mathrm{~cm}$ above soil level. Inoculated seedlings were maintained in a growth chamber under the same conditions, and, 4 days after inoculation, the pathogenicity of each strain was determined by assessing brown stripe development around the inoculation site.

The growth of each bacterial strain was assessed in inoculated plants up to 4 days after inoculation. Three sets of randomly selected rice plants were harvested, were rinsed thoroughly in $1 \% \mathrm{HClO}, 70 \%$ ethanol, and sterile water, and were homogenized in distilled water. Dilutions of the homogenate were plated onto Pseudomonas $\mathrm{F}$ agar. After incubation for $48 \mathrm{~h}$ at $30^{\circ} \mathrm{C}$, the number of $\mathrm{CFU}$ was determined.

\section{ACKNOWLEDGMENTS}

We are grateful to Y. Nakagawa for excellent technical support.

\section{LITERATURE CITED}

Arnold, R., Brandmaier, S., Kleine, F., Tischler, P., Heinz, E., Behrens, S., Niinikoski, A., Mewes, H. W., Horn, M., and Rattei, T. 2009. Sequence-based prediction of type III secreted proteins. PLoS Pathog. 5:e1000376.

Baba, A., Hasezawa, S., and Syono, K. 1986. Cultivation of rice protoplasts and their transformation mediated by Agrobacterium spheroplasts. Plant Cell Physiol. 27:463-472.

Baillieul, F., de Ruffray, P., and Kauffmann, S. 2003. Molecular cloning and biological activity of $\alpha-, \beta-$, and $\gamma$-megaspermin, three elicitins secreted by Phytophthora megasperma $\mathrm{H}_{20}$. Plant Physiol. 131:155-166.

Boller, T., and Felix, G. 2009. A renaissance of elicitors: Perception of microbe-associated molecular patterns and danger signals by patternrecognition receptors. Annu. Rev. Plant Biol. 60:379-406.

Casper-Lindley, C., Dahlbeck, D., Clark, E. T., and Staskawicz, B. J. 2002. Direct biochemical evidence for type III secretion-dependent translocation of the AvrBs2 effector protein into plant cells. Proc. Natl. Acad. Sci. U.S.A. 99:8336-8341.

Che, F. S., Iwano, M., Tanaka, N., Takayama, S., Minami, E., Shibuya, N., Kadota, I., and Isogai, A. 1999. Biochemical and morphological features of rice cell death induced by Pseudomonas avenae. Plant Cell Physiol. 40:1036-1045.

Che, F. S., Nakajima, Y., Tanaka, N., Iwano, M., Yoshida, T., Takayama, S., Kadota, I., and Isogai, A. 2000. Flagellin from an incompatible strain of Pseudomonas avenae induces a resistance response in cultured rice cells. J. Biol. Chem. 275:32347-32356.

Cheng, W., Munkvold, K. R., Gao, H., Mathieu, J., Schwizer, S., Wang, S., Yan, Y. B., Wang, J., Martin, G. B., and Chai, J. 2011. Structural analysis of Pseudomonas syringae AvrPtoB bound to host BAK1 reveals two 
similar kinase-interacting domains in a type III Effector. Cell Host Microbe 10:616-626.

Ducey, T. F., and Dyer, D. W. 2002. Rapid identification of EZ:TN ${ }^{\mathrm{TM}}$ transposon insertion sites in the genome of Neisseria gonorrhoeae. EPICENTRE Forum 9:6-7.

Felix, G., Duran, J. D., Volko, S., and Boller, T. 1999. Plants have a sensitive perception system for the most conserved domain of bacterial flagellin. Plant J. 18:265-276.

Furukawa, T., Inagaki, H., Takai, R., Hirai, H., and Che, F. S. 2014. Two distinct EF-Tu epitopes induce immune responses in rice and Arabidopsis. Mol. Plant-Microbe Interact 27:113-124.

Gimenez-Ibanez, S., Hann, D. R., Chang, J. H., Segonzac, C., Boller, T., and Rathjen, J. P. 2018. Differential suppression of Nicotiana benthamiana innate immune responses by transiently expressed Pseudomonas syringae type III effectors. Front. Plant Sci. 9:688.

Gimenez-Ibanez, S., Hann, D. R., Ntoukakis, V., Petutschnig, E., Lipka, V., and Rathjen, J. P. 2009. AvrPtoB targets the LysM receptor kinase CERK1 to promote bacterial virulence on plants. Curr. Biol. 19:423-429.

Göhre, V., Spallek, T., Häweker, H., Mersmann, S., Mentzel, T., Boller, T., de Torres, M., Mansfield, J. W., and Robatzek, S. 2008. Plant patternrecognition receptor FLS2 is directed for degradation by the bacterial ubiquitin ligase AvrPtoB. Curr. Biol. 18:1824-1832.

Gómez-Gómez, L., and Boller, T. 2000. FLS2: An LRR receptor-like kinase involved in the perception of the bacterial elicitor flagellin in Arabidopsis. Mol. Cell 5:1003-1011.

Hirai, H., Takai, R., Iwano, M., Nakai, M., Kondo, M., Takayama, S., Isogai, A., and Che, F. S. 2011. Glycosylation regulates specific induction of rice immune responses by Acidovorax avenae flagellin. J. Biol. Chem. 286:25519-25530.

Jones, J. D., and Dangl, J. L. 2006. The plant immune system. Nature 444: 323-329.

Kadota, I., Mizuno, A., and Nishiyama, K. 1996. Detection of a protein specific to the strain of Pseudomonas avenae Manns 1909 pathogenic to rice. Ann. Phytopathol. Soc. Jpn. 62:425-428.

Kadota, Y., Shirasu, K., and Zipfel, C. 2015. Regulation of the NADPH oxidase RBOHD during plant immunity. Plant Cell Physiol. 56:1472-1480.

Kaku, H., Nishizawa, Y., Ishii-Minami, N., Akimoto-Tomiyama, C., Dohmae, N., Takio, K., Minami, E., and Shibuya, N. 2006. Plant cells recognize chitin fragments for defense signaling through a plasma membrane receptor. Proc. Natl. Acad. Sci. U.S.A. 103:11086-11091.

Kaneda, T., Taga, Y., Takai, R., Iwano, M., Matsui, H., Takayama, S., Isogai, A., and Che, F. S. 2009. The transcription factor OsNAC4 is a key positive regulator of plant hypersensitive cell death. EMBO J. 28:926-936.

Katsuragi, Y., Takai, R., Furukawa, T., Hirai, H., Morimoto, T., Katayama, T., Murakami, T., and Che, F. S. 2015. CD2-1, the C-terminal region of flagellin, modulates the induction of immune responses in rice. Mol. Plant-Microbe Interact 28:648-658.

Kimura, S., Hunter, K., Vaahtera, L., Tran, H. C., Citterico, M., Vaattovaara, A., Rokka, A., Stolze, S. C., Harzen, A., Meißner, L., Wilkens, M. M. T., Hamann, T., Toyota, M., Nakagami, H., and Wrzaczek, M. 2020. CRK2 and C-terminal phosphorylation of NADPH oxidase RBOHD regulate reactive oxygen species production in Arabidopsis. Plant Cell 32:1063-1080.

Klarzynski, O., Plesse, B., Joubert, J. M., Yvin, J. C., Kopp, M., Kloareg, B., and Fritig, B. 2000. Linear beta-1,3 glucans are elicitors of defense responses in tobacco. Plant Physiol. 124:1027-1038.

Kondo, M., Hirai, H., Furukawa, T., Yoshida, Y., Suzuki, A., Kawaguchi, T., and Che, F. S. 2017. Frameshift mutation confers function as virulence factor to leucine-rich repeat protein from Acidovorax avenae. Front. Plant Sci. 7:1988.

Kunze, G., Zipfel, C., Robatzek, S., Niehaus, K., Boller, T., and Felix, G. 2004. The $\mathrm{N}$ terminus of bacterial elongation factor $\mathrm{Tu}$ elicits innate immunity in Arabidopsis plants. Plant Cell 16:3496-3507.
Laquitaine, L., Gomès, E., François, J., Marchive, C., Pascal, S., Hamdi, S., Atanassova, R., Delrot, S., and Coutos-Thévenot, P. 2006. Molecular basis of ergosterol-induced protection of grape against Botrytis cinerea: Induction of type I LTP promoter activity, WRKY, and stilbene synthase gene expression. Mol. Plant-Microbe Interact 19:1103-1112.

Li, L., Li, M., Yu, L., Zhou, Z., Liang, X., Liu, Z., Cai, G., Gao, L., Zhang, X., Wang, Y., Chen, S., and Zhou, J. M. 2014. The FLS2-associated kinase BIK1 directly phosphorylates the NADPH oxidase RbohD to control plant immunity. Cell Host Microbe 15:329-338.

Macho, A. P., Schwessinger, B., Ntoukakis, V., Brutus, A., Segonzac, C., Roy, S., Kadota, Y., Oh, M. H., Sklenar, J., Derbyshire, P., LozanoDurán, R., Malinovsky, F. G., Monaghan, J., Menke, F. L., Huber, S. C., He, S. Y., and Zipfel, C. 2014. A bacterial tyrosine phosphatase inhibits plant pattern recognition receptor activation. Science 343:1509-1512.

Matelska, D., Steczkiewicz, K., and Ginalski, K. 2017. Comprehensive classification of the PIN domain-like superfamily. Nucleic Acids Res. 45:6995-7020.

Nakano, M., and Mukaihara, T. 2019. Comprehensive identification of PTI suppressors in type III effector repertoire reveals that Ralstonia solanacearum activates jasmonate signaling at two different steps. Int. J. Mol. Sci. 20:5992-6008.

Ootsubo, Y., Hibino, T., Wakazono, T., Mukai, Y., and Che, F. S. 2016. IREN, a novel EF-hand motif-containing nuclease, functions in the degradation of nuclear DNA during the hypersensitive response cell death in rice. Biosci. Biotechnol. Biochem. 80:748-760.

Qin, J., Zhou, X., Sun, L., Wang, K., Yang, F., Liao, H., Rong, W., Yin, J., Chen, H., Chen, X., and Zhang, J. 2018. The Xanthomonas effector XopK harbours E3 ubiquitin-ligase activity that is required for virulence. New Phytol. 220:219-231.

Romeis, T., Piedras, P., Zhang, S., Klessig, D. F., Hirt, H., and Jones, J. D. 1999. Rapid Avr9- and Cf-9 -dependent activation of MAP kinases in tobacco cell cultures and leaves: Convergence of resistance gene, elicitor, wound, and salicylate responses. Plant Cell 11:273-287.

Schechter, L. M., Roberts, K. A., Jamir, Y., Alfano, J. R., and Collmer, A. 2004. Pseudomonas syringae type III secretion system targeting signals and novel effectors studied with a Cya translocation reporter. J. Bacteriol. 186:543-555.

Schwacke, R., and Hager, A. 1992. Fungal elicitors induce a transient release of active oxygen species from cultured spruce cells that is dependent on $\mathrm{Ca}^{2+}$ and protein-kinase activity. Planta 187:136-141.

Silipo, A., Molinaro, A., Sturiale, L., Dow, J. M., Erbs, G., Lanzetta, R., Newman, M. A., and Parrilli, M. 2005. The elicitation of plant innate immunity by lipooligosaccharide of Xanthomonas campestris. J. Biol. Chem. 280:33660-33668.

Takai, R., Isogai, A., Takayama, S., and Che, F. S. 2008. Analysis of flagellin perception mediated by flg22 receptor OsFLS2 in rice. Mol. Plant-Microbe Interact 21:1635-1642.

Takai, R., Kaneda, T., Isogai, A., Takayama, S., and Che, F. S. 2007. A new method of defense response analysis using a transient expression system in rice protoplasts. Biosci. Biotechnol. Biochem. 71:590-593.

Tanaka, N., Che, F. S., Watanabe, N., Fujiwara, S., Takayama, S., and Isogai, A. 2003. Flagellin from an incompatible strain of Acidovorax avenae mediates $\mathrm{H}_{2} \mathrm{O}_{2}$ generation accompanying hypersensitive cell death and expression of $P A L, C h t-1$, and $P B Z 1$, but not of Lox in rice. Mol. Plant-Microbe Interact 16:422-428.

Wu, D., Ding, W., Zhang, Y., Liu, X., and Yang, L. 2015. Oleanolic acid induces the type III secretion system of Ralstonia solanacearum. Front. Microbiol. 6:1466.

Yoshie, Y., Goto, K., Takai, R., Iwano, M., Takayama, S., Isogai, A., and Che, F. S. 2005. Function of the rice gp91 ${ }^{\text {phox }}$ homologs OsrbohA and OsrbohE genes in ROS-dependent plant immune responses. Plant Biotechnol. 22:127-135. 